Review

\title{
Exploiting the Pleiotropic Antioxidant Effects of Established Drugs in Cardiovascular Disease
}

\author{
Sebastian Steven ${ }^{1,2, \dagger}$, Thomas Münzel ${ }^{1, \dagger}$ and Andreas Daiber ${ }^{1, \dagger}, *$ \\ 1 2nd Medical Clinic, University Medical Center of the Johannes Gutenberg-University, \\ Mainz 55131, Germany; E-Mails: Sebastiansteven@gmx.de (S.S.); tmuenzel@uni-mainz.de (T.M.) \\ 2 Center for Thrombosis and Hemostasis, University Medical Center of \\ the Johannes Gutenberg-University, Mainz 55131, Germany \\ $\dagger$ These authors contributed equally to this work. \\ * Author to whom correspondence should be addressed; E-Mail: daiber@uni-mainz.de; \\ Tel.: +49-(0)6131-17-6280; Fax: +49-(0)6131-17-6293.
}

Academic Editor: G. Jean Harry

Received: 26 June 2015 / Accepted: 27 July 2015 / Published: 5 August 2015

\begin{abstract}
Cardiovascular disease is a leading cause of death and reduced quality of life worldwide. Arterial vessels are a primary target for endothelial dysfunction and atherosclerosis, which is accompanied or even driven by increased oxidative stress. Recent research in this field identified different sources of reactive oxygen and nitrogen species contributing to the pathogenesis of endothelial dysfunction. According to lessons from the past, improvement of endothelial function and prevention of cardiovascular disease by systemic, unspecific, oral antioxidant therapy are obviously too simplistic an approach. Source- and cell organelle-specific antioxidants as well as activators of intrinsic antioxidant defense systems might be more promising. Since basic research demonstrated the contribution of different inflammatory cells to vascular oxidative stress and clinical trials identified chronic inflammatory disorders as risk factors for cardiovascular events, atherosclerosis and cardiovascular disease are closely associated with inflammation. Therefore, modulation of the inflammatory response is a new and promising approach in the therapy of cardiovascular disease. Classical anti-inflammatory therapeutic compounds, but also established drugs with pleiotropic immunomodulatory abilities, demonstrated protective effects in various models of cardiovascular disease. However, results from ongoing clinical trials are needed to further evaluate the value of immunomodulation for the treatment of cardiovascular disease.
\end{abstract}


Keywords: cardiovascular disease; endothelial dysfunction; oxidative stress; inflammation; dipeptidyl peptidase-4 inhibitors; glucagon-like peptide analogs

\section{Oxidative Stress in Cardiovascular Disease and Inflammation}

\subsection{Introduction}

The majority of cardiovascular diseases are accompanied by an imbalance between the formation of reactive oxygen species (ROS, including superoxide, hydrogen peroxide as well as precursor products peroxynitrite or hypochlorous acid) and antioxidant enzymes [1,2], leading to a deviation from the steady state [3]. More recent evidence suggests that adverse redox signaling and oxidative stress are not only side effects of the progression of cardiovascular disease but even potent triggers of their development and pathogenesis [4,5]. According to the "kindling radical" hypothesis (or "bonfire" concept), the formation of ROS may trigger the activation of additional sources of ROS in certain disease conditions or during the aging process [6,7]. According to recent reports, vascular dysfunction in general, but hypertension and coronary artery disease may also be linked to inflammation or low-grade activation of the immune system [8,9]. Uncoupling of endothelial nitric oxide synthase (eNOS) is a hallmark of most cardiovascular disease $[10,11]$ and endothelial dysfunction in coronary and peripheral vessels, measured by acetylcholine-dependent plethysmography or flow-mediated dilation, is an early predictor of cardiovascular events [12,13]. eNOS function is regulated by many different factors such as subcellular localization, calcium levels, binding of different co-factors (e.g., $\mathrm{BH}_{4}, \mathrm{FAD}, \mathrm{FMN}, \mathrm{NADPH}$, zinc), and other proteins (e.g., calmodulin, heat shock proteins). Regulation of eNOS activity by so-called "redox switches" is of great interest for the present review - the oxidative depletion of tetrahydrobiopterin $\left(\mathrm{BH}_{4}\right)$, oxidative disruption of the dimeric eNOS complex by oxidation of the zinc-sulfur complex, $S$-glutathionylation of a cysteine in the reductase domain, and adverse phosphorylation at Thr495/Tyr657, as well as ROS-triggered increases in levels of the endogenous eNOS inhibitor asymmetric dimethylarginine (ADMA) (for detailed review see [6,7]). Another focus of research in the cardiovascular field is the "repair" of vascular damage by improvement of the function of endothelial progenitor cells by drugs with antioxidant and other pleiotropic properties [14] or infusion of these cells after a severe insult such as myocardial infarction $[15,16]$. This topic will only be touched on with some examples but not explored in detail. The major part of this review will discuss antioxidant therapeutic interventions that prevent eNOS uncoupling, thereby normalizing endothelial function in particular and improving cardiovascular disease in general. We will emphasize the importance of low-grade inflammation in the development of endothelial dysfunction and cardiovascular disease and discuss the contribution of specific inflammatory cells and their cytokine profiles to the development and progression of cardiovascular disease.

\subsection{Inflammation, Oxidative Stress, and Endothelial Dysfunction}

The first description of the role of oxidative stress in the development and progression of cardiovascular disease in an experimental model of hypercholesterolemia was published by Harrison 
and Ohara [17,18]. According to the abovementioned concept of "kindling radicals" or the "bonfire" hypothesis, the initial formation of superoxide (e.g., from phagocytic NADPH oxidases of infiltrated leukocytes) and subsequent formation of peroxynitrite most likely triggers further damage such as eNOS uncoupling, converting this beneficial nitric oxide synthase into a detrimental superoxide-producing enzyme (Figure 1) [6,8]. Likewise, ROS from infiltrated immune cells can activate or induce expression of vascular cell oxidases such as Nox1, Nox2, or Nox4 (isoform specific catalytic subunits of NADPH oxidases), or mediate the oxidative conversion of the xanthine dehydrogenase to the oxidase form [6,19]. This ROS-induced ROS formation is well known for cross-activation of mitochondrial ROS formation by dysfunctional mitochondria [20]. Mitochondrial ROS formation and release can be stimulated by thiol-oxidation in different mitochondrial structures (e.g., mitochondrial permeability transition pore constituents such as cyclophilin $\mathrm{D}, \mathrm{p} 66^{\text {shc }}$ or monoamine oxidases); xanthine dehydrogenase is converted to the oxidase form by oxidation of critical thiol residues; the protective action of eNOS to produce $\mathrm{NO}$ is switched to adverse superoxide formation by oxidative depletion of $\mathrm{BH} 4$, adverse phosphorylation by redox-activated kinases, $S$-glutathionylation ,or oxidative disruption of the zinc-sulfur complex at the dimer binding interface, called the "uncoupling" process. These changes (increased vascular oxidative stress and release of inflammatory signaling molecules) will lead to endothelial cell activation and priming for the adhesion of additional immune cells as well as platelets and switch the vasodilatory, antiaggregatory, and antiatherosclerotic phenotype of the endothelium to a vasoconstrictory, proaggregatory, and proatherosclerotic one.

As described above, ROS formation is not only a side effect of cardiovascular diseases but directly contributes to the disease progression in many ways. For example, the induction of endothelial dysfunction by oxidative modification of eNOS or its cofactors as well as redox stimulation of inflammatory cascades fosters the progression of these cardiovascular diseases (Figure 1). Most immune cells express high levels of functional NADPH oxidases and are capable of producing ROS at much higher levels than vascular cells $[21,22]$. The important role of phagocytic NADPH oxidase in this process was demonstrated by the fact that white blood cells with dysfunctional Nox2 were not able to infiltrate the vascular wall and induce vascular oxidative stress and damage [22,23], e.g., by oxidative conversion of xanthine dehydrogenase to the oxidase form, uncoupling of eNOS, or stimulation of mitochondrial ROS formation and release by specific redox switches [6]. On the other hand, there is clear evidence that ROS formation per se contributes to a pro-inflammatory phenotype, since mitochondrial superoxide/hydrogen peroxide formation has the ability to activate immune cells [24-26]. ROS play an important role in inflammation and tissue damage [27]. There is also increasing evidence of a close interaction between vascular oxidative stress and inflammation during the aging process, leading to a vicious cycle in the aging vasculature [28]. By this crosstalk, infiltrated immune cells promote vascular oxidative stress, lead to endothelial cell activation, and prime the endothelium for the adhesion of additional leukocytes and platelets [8], which is of great importance for aging-associated endothelial dysfunction [29]. Vice versa, oxidative stress is a hallmark of all cardiovascular disease and will also lead to endothelial cell activation, priming for adhesion and infiltration of immune cells as well as activation of these infiltrated immune cells. Accordingly, most cardiovascular disease displays a low-grade inflammatory phenotype of the vasculature. 


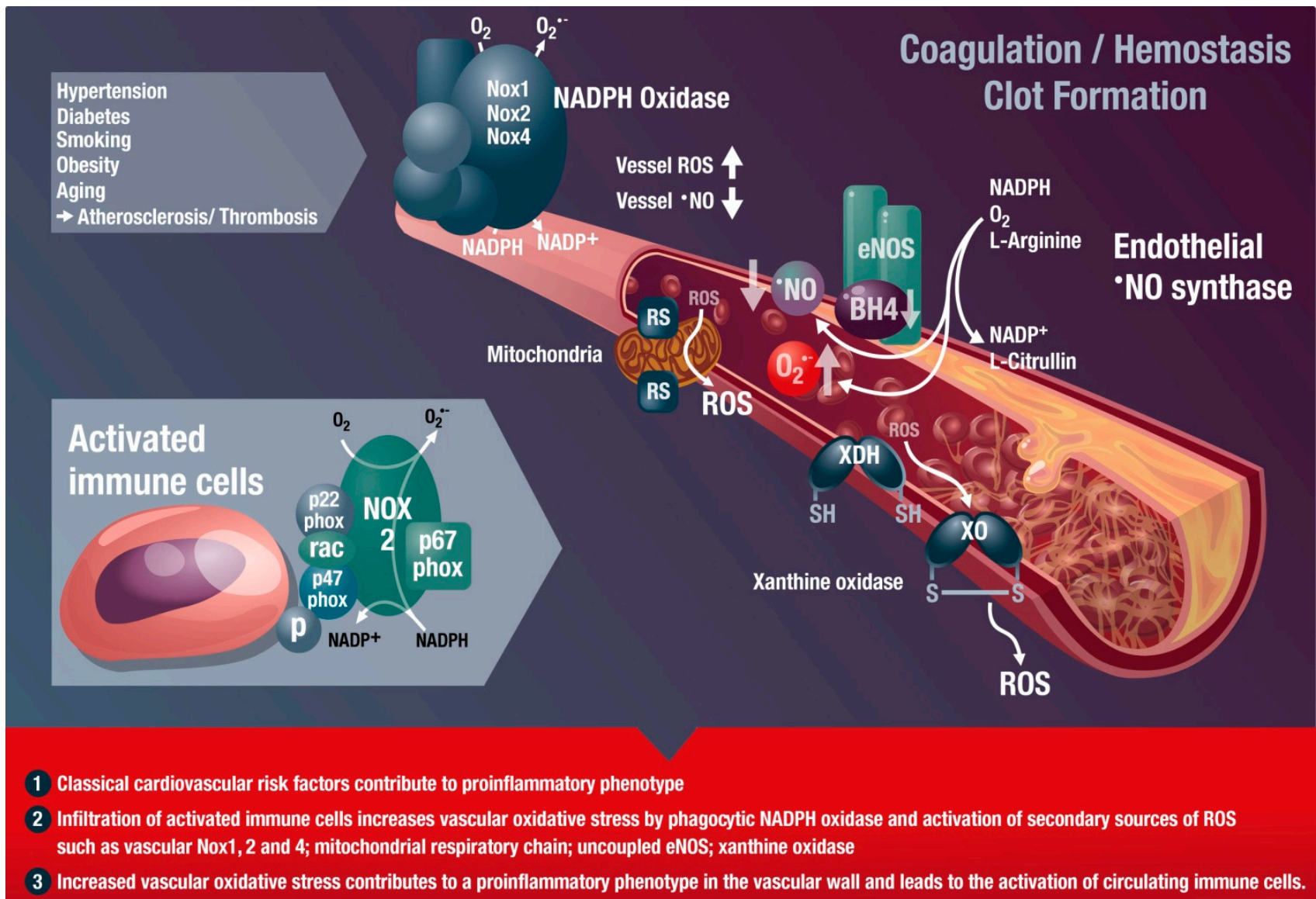

Figure 1. Inflammatory cells, vascular dysfunction, and atherothrombosis. The scheme illustrates the activation of immune cells and recruitment to vascular tissues by classical cardiovascular risk factors, leading to activation of secondary vascular ROS sources such as NADPH oxidase (Nox1, Nox2, and Nox4), xanthine oxidase (conversion of the dehydrogenase $(\mathrm{XDH})$ to the oxidase $(\mathrm{XO})$ form), mitochondria (via mitochondrial redox switches (RS)), and uncoupled eNOS (oxidative depletion of tetrahydrobiopterin (BH4) and other redox switches), all of which contribute to vascular dysfunction. Immune cells such as monocytes need the functional phagocyte-type NADPH oxidase (Nox2) in order to infiltrate vascular tissues. ROS produced by this activated Nox 2 from infiltrated immune cells will activate secondary vascular ROS sources in a redox-sensitive fashion (for review see $[19,30])$. These processes lead to late-stage cardiovascular complications such as atherosclerosis with plaque formation and thrombosis. Modified from [8]. With permission by Bentham Science Publisher. Copyright (C) 2014, Eureka Science Ltd.

Different immune cells have been reported to contribute to the development of cardiovascular disease, but since they interact with each other, the individual impact of each cell type on the development of cardiovascular disease remains elusive. The contribution of B- and T-cells to the development of hypertension by angiotensin-II infusion was demonstrated by RAG-1 ${ }^{-/-}$mice [22]. Likewise, the onset of angiotensin-II induced hypertension and vascular oxidative stress was also attenuated by removal of myelomonocytic cells [23]. Of note, immune suppressive treatment of patients with rheumatoid arthritis or psoriasis was associated with a reduction of systolic blood 
pressure [31], underlining the clinical impact of a direct contribution of the immune system to vascular dysfunction.

\subsection{Chronic Autoimmune Diseases Associated with Cardiovascular Disease}

Chronic autoimmune diseases such as systemic lupus erythematodes, rheumatoid arthritis, and severe psoriasis are associated with an increased risk for cardiovascular events [32-35]. Importantly, psoriasis was defined as an independent risk factor in addition to the classical cardiovascular risk factors such as smoking, obesity, and diabetes [36]. The European League against Rheumatism even recommends the management of cardiovascular risk in inflammatory arthritis in their guidelines [37]. As an early predictor of cardiovascular events, impaired vascular function was observed under chronic inflammation, which was evident in patients with rheumatoid arthritis by a significant increase in the intima-media thickness [38] or impaired endothelial function measured by flow-mediated dilatation in patients with psoriasis [39]. Therefore, recent clinical trials have demonstrated that increased cardiovascular mortality in patients with chronic inflammatory disease can be managed by targeting specific cytokines or activation of specific immune cells, e.g., in psoriasis the IL-17/IL-23 axis [40-42], in systemic lupus erythematodes IL-17A signaling [43], and in rheumatoid arthritis the IL-6, TNF- $\alpha$, and IL-17A cascades $[44,45]$. These data provide a feasible link between cardiovascular disease and the chronic autoimmune diseases (also reviewed in [32,34]).

\section{Classical Antioxidants and New Strategies to Modulate Oxidative Stress}

\subsection{Classical Antioxidants}

Based on the oxidative stress concept in cardiovascular, neurodegenerative, metabolic, and inflammatory disease $[5,7,8]$, numerous studies were conducted. In vitro and animal studies of these diseases were performed in order to characterize the cytoprotective or therapeutic benefit of antioxidants and to promote phytochemicals, functional foods, and antioxidant (vitamin) supplements. However, antioxidants have failed to show any therapeutic benefit in most large clinical trials that were conducted according to modern standards [46], such as HOPE (Heart Outcome Prevention Evaluation) and HOPE-TOO (Heart Outcome Prevention Evaluation-The Ongoing Outcomes), which demonstrated that vitamin E causes more heart failure and left heart decompensation [47-50] (for review see [51]). A prospective study with vitamin $\mathrm{C}$ in post-menopausal women with diabetes mellitus even demonstrated an increased incidence of cardiovascular events and mortality under antioxidant therapy [52]. The SAINT I trial investigated the therapeutic benefit of the synthetic antioxidant, NXY-059, in acute ischemic stroke but failed to show any neuroprotective effect [53]. According to Bjelakovic and coworkers, meta-analysis of 68 randomized trials with 232,606 participants revealed that the use of lipid-soluble antioxidants without medical indication may even increase mortality in adults [54]. Another meta-analysis of 14 randomized trials with 170,525 individuals by the same author demonstrated a similar trend-lipid-soluble antioxidants increased the mortality of gastrointestinal cancer patients [55]. However, other meta-analyses support the beneficial effects of vitamin $\mathrm{C}$ in specific disease conditions or disease-associated impairment of 
functional parameters, e.g., on the survival of women with breast cancer [56] or on endothelial function in patients with atherosclerosis, diabetes, and heart failure [57].

These large-scale clinical trials on chronic oral antioxidant supplementation are contrasted by multiple small cohort studies with acute (parenteral) administration of antioxidants with highly beneficial effects on the surrogate parameters of disease (e.g., endothelial dysfunction) in chronic smokers or patients with diabetes or coronary artery disease [12,58-60] (for review see [51]). The advantage of parenteral administration of water-soluble antioxidants is that high plasma concentrations of the antioxidant are achieved [61], thereby omitting the complications of oral absorption (time-lag, limited capacity) and insufficient compliance. High-dose intravenous infusion of vitamin $\mathrm{C}$ also improved endothelial function in patients with Kawasaki disease [62], kidney dysfunction [63], hypertension [64], liver cirrhosis, and portal hypertension [65]. Moreover, parenteral application of vitamin $\mathrm{C}$ has also proven to have clinical effects in patients with allergies [66], sudden hearing loss [67], breast cancer, infection, and pancreatitis [68].

A positive example of the beneficial effect of chronic antioxidant therapy is vitamin D. Lack of vitamin $\mathrm{D}$ is endemic in the human population and epidemiological data indicate that deficiency of this vitamin is associated with cardiovascular disease [69]. There is some evidence from interventional trials demonstrating that supplementation of vitamin D is beneficial to endothelial function [70,71], blood pressure [72], and cardiac hypertrophy [73,74] in humans. Furthermore, a recent Cochrane analysis revealed that vitamin D supplementation significantly reduces cardiovascular mortality in elderly people [75]. Nevertheless, further large-scale randomized placebo-controlled clinical trial are needed to elucidate the cardiovascular protective effects of vitamin D. In contrast to other vitamins, deficiency of vitamin D is very common, especially in older individuals [76], which might be the explanation for the beneficial effects of vitamin $\mathrm{D}$, especially on cardiovascular disease in the elderly [77].

Based on the disappointing results of most large-scale clinical trials (HOPE, HOPE-TOO) [47,49] (reviewed in [51]), with chronic oral antioxidants supplementation the question arises whether the oxidative stress hypothesis in pathogenesis and disease progression is wrong? We think the answer is no and possible explanations for the lack of clinical efficacy of antioxidants in these studies might be that: (1) vitamins $\mathrm{C}$ and $\mathrm{E}$ act as pro-oxidants; (2) the coronary artery disease of the patients included in the studies is already irreversible; (3) the coronary artery disease patients are already being treated with drugs displaying antioxidant properties (for example, ACE inhibitors and angiotensin type 1 receptor blockers; see also Section 3); (4) chronic antioxidant therapy inhibits intrinsic ischemic preconditioning, which relies on ROS formation; and (5) oral vitamin treatment does not result In high enough concentrations of the antioxidants at the place of oxidative stress (summarized from [5]). Another important drawback of classical antioxidants may be the slow reaction between $\mathrm{O}_{2}{ }^{--}$and vitamins $\mathrm{C}$ and $\mathrm{E}$ (with rate constants of $3.3 \times 10^{5}$ and $4.9 \times 10^{3} \mathrm{M}^{-1} \cdot \mathrm{s}^{-1}$, respectively, compared with $1.9 \times 10^{10} \mathrm{M}^{-1} \cdot \mathrm{s}^{-1}$ for the reaction between $\mathrm{NO}$ and $\mathrm{O}_{2}{ }^{--}$) [78]. Finally, in most of the abovementioned large-scale clinical trials on the use of chronic oral antioxidant supplementation, the compliance of the patients was not controlled (e.g., by measurement of plasma levels of the antioxidants). The important role of controlled antioxidant plasma levels became evident in the EPIC Norfalk study, demonstrating that vitamin $\mathrm{C}$ concentrations in the blood inversely correlate with all-cause mortality in healthy volunteers [79]. In addition, there was an inverse correlation between circulating vitamin $\mathrm{C}$ concentrations 
and risk of stroke as reported by a meta-analysis [80]. According to a concept put forward by Lykkesfeldt and colleagues [81], better results of antioxidant therapy might be expected under conditions of antioxidant deficiency (e.g., for vitamin $\mathrm{C}$ and $\mathrm{E}$ ) [82], or often encountered for vitamin D [76]. Some of these reasons would favor a proper prediagnosis of patients for blood levels of antioxidants, strict monitoring of this parameter during antioxidant therapy, and acute infusion of vitamin $\mathrm{C}$ in accordance with the observations and advantages of parenteral use discussed above. According to a recent review on the use of antioxidants in translational medicine, future antioxidant strategies will not be based on the classical antioxidant vitamins (apart from some acute situations with subclinical deficiencies as well as parenteral instead of oral therapy) but rather on the activation of endogenous antioxidant enzyme systems, inhibition of critical ROS sources (e.g., NADPH oxidase), the repair of oxidatively damaged structures, or site-directed antioxidant approaches [51].

\subsection{New Antioxidant Strategies}

Direct and cell organelle-specific targeting of ROS formation is a new promising strategy. A prominent example is scavenging mitochondrial ROS by mitochondria-targeted antioxidants such as mitoquinone (mitoQ) [83,84], a quinone that is coupled to a triphenylphosphonium group to facilitate mitoQ accumulation in mitochondria by up to 10,000-fold. MitoQ showed beneficial effects in an animal model and in human cells from patients with chronic obstructive pulmonary disease [85], improved nitrate-tolerance-associated side effects of nitroglycerin therapy in rats [86], and normalized endothelial function and cardiac hypertrophy in stroke-prone spontaneously hypertensive rats [87]. Moreover, MitoQ showed neuroprotective effects in experimental amyotrophic lateral sclerosis [88], suppressed NLRP3 inflammasome-mediated inflammatory cytokines in a murine colitis model [89], beneficially influenced nephropathy in diabetic mice [90], and prevented cardiac ischemia-reperfusion injury in rats [84]. According to recent data, another mitochondria-targeted antioxidant, mitoTEMPO, prevented adverse effects of angiotensin-II in experimental hypertension [91]. Similar beneficial effects have been reported for the use of mitochondria-targeted SOD mimetics such as $\mathrm{Mn}$ (III) 5,10,15,20-tetrakis( $N$-methylpyridinium-2-yl)porphyrin $\left(\mathrm{MnTM}-2-\mathrm{PyP}^{5+}\right.$ ) in various disease models [92,93]. Several compounds of the class of mitochondria-targeted antioxidants are currently in late phase clinical trials (for review see [92-95]; for ongoing clinical trials visit www.clinicaltrials.gov). A limitation of the use of mitochondria-targeted antioxidants might be that viable mitochondria with intact membrane potential are required for their mitochondrial accumulation, which could interfere with their uptake, especially in dysfunctional, ROS-producing mitochondria. A similar idea provides the basis for endothelium-targeted antioxidants. Shuvaev et al. demonstrated that targeting of SOD, but not catalase, to the endothelium reversed angiotensin II-induced endothelial dysfunction [96], nicely demonstrating that $\mathrm{O}_{2}{ }^{--}$is a more harmful species in the vascular system than $\mathrm{H}_{2} \mathrm{O}_{2}$. The antioxidant enzymes SOD and catalase were conjugated with an antibody against PECAM-1 (platelet/endothelial cell adhesion molecule-1) to ensure endothelial binding. Another strategy would be to covalently bind SOD mimetics or antioxidants to heparin [97], which will lead to the binding of these antioxidant compounds to heparin-binding sites on the endothelial cell layer $[98,99]$.

Modulation/regulation of endogenous antioxidant defense systems or ROS sources by miRNAs (e.g., antagomirs), epigenetic drugs (e.g., modulators of histone acetyl transferases or deacetylases), 
or phytochemicals are other completely new antioxidant strategies [100-106]. Resveratrol, a phytochemical antioxidant, was previously regarded as a direct ROS scavenger, but more recent data revealed that it mostly acts via indirect antioxidant mechanisms [107], e.g., by modulation of gene expression via miRNAs, epigenetic modifications, and direct effects on proteins of the DNA repair machinery [108-110]. Besides resveratrol, there are hundreds of these phytochemical antioxidant compounds, in many cases with proven therapeutic effects and in some cases even with mechanistic explanations for these observed clinical effects. One prominent example is Ginkgo biloba, which has been in clinical use for a long time, especially for dementia therapy but also for its positive effects on cardiovascular disease [111].

Other antioxidant strategies are only briefly mentioned here (we refer to the respective review articles, e.g., [51]) and are based on: (1) the inhibition of disease-relevant ROS sources such as inhibitors of NADPH oxidase (Nox) enzymes [112-115] or xanthine oxidase [116,117]; (2) upregulation of the endogenous antioxidant defense system such as Nrf2 agonists [118]; and (3) repair of oxidatively damaged protein structures as exemplified by activators of heme-deficient or oxidized soluble guanylyl cyclase [119-121]. According to Stocker and colleagues, an antioxidant should ideally be recycled by cellular reducing systems, act catalytically to prevent its consumption, or induce endogenous antioxidant defense systems rather than act as a direct scavenger (for review see [122]).

\section{Antioxidants 2.0-Pleiotropic Antioxidant Effects of Established Drugs}

It would be beyond the scope of this review to discuss all of the important representatives of this group of drugs, so the following will be limited to some examples of new function for old drugs. The pleiotropic antioxidant effects of these compounds are characterized by different modes of action (as already described above): (1) induction of intrinsic antioxidant systems; (2) inhibition of Nox2-dependent ROS formation; and (3) direct ROS scavenging activity. It remains to be established whether some of these pleiotropic antioxidant effects are just a consequence of the primary pharmacological action of the drugs (e.g., lowering of blood pressure). At least in some of the examples the primary pharmacological action of the drugs can be excluded since data were obtained either in cell culture or even with isolated enzymatic systems.

\subsection{Statins, ACE-Inhibitors, and AT1-Receptor Blockers}

Angiotensin-converting enzyme inhibitors, type 1 angiotensin II receptor antagonists, statins, and many other cardiovascular drugs display pleiotropic indirect antioxidant properties (e.g., inhibition of Nox enzymes and secondary to this prevention of eNOS uncoupling) [123,124]. In more detail, angiotensin-converting enzyme inhibitors and type 1 angiotensin II receptor antagonists increase the bioavailability of $\mathrm{NO}$ by decreased breakdown of bradykinin and activation of the corresponding B2 receptor [125]. They also prevent the activation of the phagocytic and vascular Nox2 enzyme and thereby decrease cellular superoxide, hydrogen peroxide, and peroxynitrite levels [126]. Inhibition of angiotensin-II signaling decreases oxidative stress since angiotensin-II via its receptor leads to the formation of diacylglycerol, a potent endogenous trigger of NADPH oxidase activity [127]. In addition, these drugs confer potent anti-inflammatory effects by interfering with the adhesion of monocytes to the endothelium [128] and even improving the severity of adjuvant arthritis [129]. In 
summary, angiotensin-converting enzyme inhibitors and type 1 angiotensin II receptor antagonists promote a vasodilatory, antithrombotic, and antiproliferative milieu and improve the function of endothelial progenitor cells [130]. These protective mechanisms might also explain their benefit for the therapy of patients with heart failure [131]. Statins obviously target exactly the same pathophysiological parameters. In patients with cardiovascular disease, statins reduce vascular inflammation and atherothrombosis, which causes cardiovascular events like myocardial infarction [132-134]. Statins reduce NADPH oxidase activity in a Rac1-dependent mechanism [135,136] and improve the bioavailability of $\mathrm{NO}$ through increased levels of the eNOS cofactor BH4, decreased levels of the endogenous eNOS inhibitor asymmetric dimethyl-L-arginine, decreased caveolin-1 activity, improved activating eNOS phosphorylation, and upregulation of eNOS mRNA [137]. The beneficial pleiotropic effects of statins are probably based on the induction of the Nrf2-heme oxygenase-1 system [138,139] but improvement of the function of endothelial progenitor cells could also contribute to their protective profile [140].

\subsection{Nebivolol, Hydralazine, and Pentaerythrityl Tetranitrate (PETN)}

One of the first known antihypertensive drugs was hydralazine, which is today mainly used for the treatment of pre-eclampsia [141]. However, it experienced a "revival" when the company NitroMed introduced their combination drug BiDil containing hydralazine and isosorbide dinitrate. This combination therapy showed an impressive decrease in mortality in African-Americans with severe heart failure, who responded poorly to ACE inhibitors and other standard medications (the study design was based on data from V-HeFT (Vasodilator Heart Failure Trial) and A-HeFT (African-American Heart Failure Trial) [142-144]. According to our previous observations, hydralazine is a highly efficient peroxynitrite scavenger and prevents tyrosine nitration [145,146], which may at least contribute to its beneficial effects on nitroglycerin-induced nitrate tolerance [147] and potentially isosorbide dinitrate-associated side effects. Based on these data, we postulate a direct antioxidant property of hydralazine by scavenging peroxynitrite, a potentially harmful oxidant. This provides the rationale for the beneficial effects of the hydralazine/isosorbide dinitrate combination to prevent side effects of the organic nitrate under chronic therapy (e.g., endothelial dysfunction [148]). Recent data support a reaction between peroxynitrite and dihydralazine sulfate [149]. However, there is also evidence for the indirect antioxidant effects of hydralazine by induction of hypoxia-inducible factor-1 $\alpha$, vascular endothelial growth factor, and angiogenesis by inhibition of prolyl hydroxylases [150]. Among other antihypertensive drugs, hydralazine has been found to possess pleiotropic antioxidant effects in patients beyond the direct blood pressure lowering effects [151]. Also, protective effects of hydralazine on endothelial progenitor cell function were reported [152].

The third generation beta-blocker nebivolol was reported to induce vascular nitric oxide formation via stimulation of eNOS activity in ex vivo studies [153-155], providing the rationale for improved NO bioavailability in patients with essential hypertension [156]. In this clinical study a combination therapy of nebivolol/bendrofluazide, in contrast to atenolol/bendrofluazide treatment, improved $\mathrm{NO}$ bioavailability despite a similar degree of blood pressure lowering. We could detect eNOS-stimulating effects of nebivolol neither in cultured endothelial cells nor in hypertensive mice when comparing wild-type controls with eNOS knockout mice (unpublished data, Karbach et al. and Daiber). We have 
previously shown that nebivolol, in contrast to metoprolol and atenolol, prevents eNOS uncoupling and induction of phagocytic NADPH oxidase activity in white blood cells, vascular oxidative stress, and endothelial dysfunction in hyperlipidemic Watanabe (WHHL) rabbits [157]. In a subsequent study we characterized nebivolol as a potent Nox2 inhibitor in hypertensive rats as well as isolated cells, which are not shared by first- and second-generation beta-blockers [158]. Nebivolol directly interferes with the assembly of Nox 2 and cytosolic subunits $\mathrm{p} 47^{\mathrm{phox}}, \mathrm{p} 67^{\mathrm{phox}}$, and rac1 in the cytoplasmic membrane, suggesting that Nox2 inhibition leads to reduced superoxide formation, prevents eNOS uncoupling and breakdown of nitric oxide by reaction with superoxide, and finally ameliorates endothelial function. This concept goes hand in hand with human data in which nebivolol normalized oxidative stress in hypertensive patients and led to reduced oxidative degradation of nitric oxide [159]. Finally, nebivolol improved the function of early endothelial progenitor cells in experimental myocardial infarction, which could also contribute to its beneficial clinical profile [160].

After the development of pentaerithrityl tetranitrate (PETN) for the U.S. market, it was abandoned, but then used for many years in the former Eastern German Republic. After the reunion of Germany, PETN became the best-selling nitrate on the German market. PETN is the only organic nitrate in clinical use devoid of induction of nitrate tolerance, endothelial dysfunction, and other nitrate-associated side effects in volunteers [161,162] and patients with coronary artery disease $[163,164]$. The molecular explanation for the beneficial effects of PETN, not shared by other nitrates, is the induction of heme oxygenase-1 [165-168] in a Nrf2-dependent fashion [169]. PETN also induced extracellular superoxide dismutase [170], prevented vascular complications in experimental diabetes and hypertension [165,169], prevented the progression of atherosclerosis in a rabbit model [171], and inhibited platelet aggregation in heart failure [172]. In contrast to other organic nitrates, PETN improved the function (migration and incorporation) of endothelial progenitor cells and decreased their NADPH oxidase activity ex vivo and in vivo in humans and rats [173-175]. In addition, PETN therapy leads to the regulation of more than 1200 genes and upregulates several cardio-protective transcription factors, whereas nitroglycerin, also a nitrovasodilator, regulated approximately 500 genes different from those regulated by PETN [176]. More recently, PETN was shown to induce heritable epigenetic changes envisaged by $\mathrm{H} 3 \mathrm{~K} 27$ acetylation, $\mathrm{H} 3 \mathrm{~K} 4$ trimethylation, and transcriptional activation of eNOS, MnSOD, glutathione peroxidase-1, and heme oxygenase-1, all of which lead to reduced blood pressure in female offspring of PETN-treated hypertensive rats [177]. Of note, these beneficial effects were neither shared by other organic nitrates nor by the NO donors tested in this study. The ongoing CAESAR trial (Clinical efficacy study of Pentalong for pulmonary hypertension in heart failure; EudraCT Number: 2009-015059-26) will show whether the potent antioxidant and vasculoprotective effects of PETN can be translated to patients with pulmonary hypertension as a result of heart failure.

\subsection{Gliptins and Glucagon-Like Peptide-1 (GLP-1) Analogs Display Antioxidant and Anti-Inflammatory Properties}

Dipeptidyl peptidase-4 (DPP-4) is an exopeptidase also known as CD26. N-terminal dipeptides are cleaved from alanine- and proline-rich proteins [178]. Besides DPP-4, the family of DPPs consists of several members: DPP-1-DPP-4, DPP-6-DPP-9, quiescent cell proline dipeptidase (QPP), and fibroblast activation protein (FAP) [178,179]. DPP-4 has a wide range of functions, the best 
characterized of which is the degradation of incretins (glucagon-like peptide-1 (GLP-1) and gastric inhibitory polypeptide GIP) [179]. Furthermore, DPP-4 cleaves non-incretin peptides, possesses non-enzymatic function, and interacts with membrane bound proteins as a chaperone [179]. In various tissues DPP-4 is expressed on the surface of endothelial cells, epithelial cells, and inflammatory cells (monocytes, lymphocytes, dendritic cells, and natural killer (NK) cells) [180-183].

GLP-1 is an incretin hormone released from L-cells in the intestine after food uptake $[184,185]$. In the context of glucose homeostasis, circulating GLP-1 binds to its receptor, which is expressed on pancreatic beta-cells, but also on cardiomyocytes, endothelial cells, and inflammatory cells. The GLP-1 receptor belongs to the family of G-protein-coupled receptors. After binding of GLP-1 to its receptor, cAMP levels rise and insulin release is stimulated. On pancreatic alpha-cells, GLP-1 reduces glucagon release (for review see [186]). In summary, GLP-1 is involved in glycemic control, which makes it an attractive target for treatment of diabetes [187,188]. Derived from the prolucagon gene, GLP-1 (7-36-amide) and GLP-1 (7-37) are secreted. Due to rapid degradation of GLP-1 to GLP-1 (9-36-amide) by DPP-4, the half-life of GLP-1 is below 2 min [189,190]. There are two pharmacological strategies for using the GLP-1 effects on glucose metabolism in diabetic patients: (1) inhibition of DPP-4 by gliptins to increase GLP-1 levels and (2) supplementation of modified GLP-1, which resists degradation by DPP-4. At the time of this review five DPP-4 inhibitors are approved by the European Medicines Agency (EMA) (vildagliptin, alogliptin, sitagliptin, linagliptin, and saxagliptin) for treatment of type 2 diabetes mellitus, also reflected by the Global Guideline for Type 2 Diabetes [191]. GLP-1 analogs are represented by liraglutide and exenatide, also reflected by the Global Guideline for Type 2 Diabetes [191].

Besides their potent effects on glycemic control in diabetic patients, research of the last years revealed their effects on several other cell types and tissues. In vivo and in vitro studies demonstrated the beneficial effects of DPP-4 inhibitors on cardiovascular disease [192,193], but also in diseases like psoriasis [194], hepatic steatosis [195], or stroke [196]. Interestingly, pathogenesis of all of these diseases has oxidative stress and most likely inflammation in common. Finally, DPP-4 inhibitors improved the number and "homing" of endothelial progenitor cells in animal [197,198] and human [199] studies, but the number of publications on this association is still low. GLP-1 analogs seem to share these effects on endothelial progenitor cells [200].

Oeseburg et al. published evidence for a protective effect of DPP-4 inhibition on oxidative stress-induced DNA damage and cellular senescence in Zucker diabetic fatty rats [201]. The authors propose elevated GLP-1 to be responsible since the effect could be blocked by exendin fragment 9-39, which is a GLP-1 receptor antagonist. According to this study, induction of the antioxidant enzymes heme oxygenase-1 and NADPH dehydrogenase (quinone) via protein kinase A activation are responsible for the beneficial effects [201]. The mentioned study is an excellent example of the difficulty of differentiating between the direct GLP-1 effects and the GLP-1-independent effects of DPP-4 inhibition. Others detected reduced oxidative stress under DPP-4 inhibitor therapy in animal models of type 1 diabetes [202], cardiac ischemia/reperfusion-injury [203], chronic myocardial infarction [204], abdominal aortic aneurysm [205], Parkinson's diseases [206], and sepsis [207,208]. Furthermore, limited data are available on the reduction of oxidative stress by DPP-4 inhibition in humans. Shah et al. found reduced 3-nitrotyrosine levels in isolated human pancreatic cells after treatment with linagliptin [209], which agrees with the findings in gliptin-treated type 2 diabetic 
patients [210]. In humans it remains unclear whether DPP-4 inhibitor-dependent reduction of oxidative stress is independent of glucose-lowering effects. However, there is clear evidence for glucose-independent reduction of oxidative stress by DPP-4 inhibition in different animal models.

DPP4 inhibition has been shown to reduce oxidative stress in various disease models. Reports on diabetes [211,212], atherosclerosis [192,193], sepsis [207,208], and neurological disease [213] can be found in the literature. AMP-activated protein kinase (AMPK) is an important regulator of oxidative stress in the vasculature, more specifically in endothelial cells [214]. Activation of AMPK via GLP-1 receptor signaling has been shown to reduce oxidative stress in cardiomyocytes and reduces activation of NADPH oxidase [215]. On the other hand, suppression of protein kinase C (PKC)/NFkB-dependent Nox activation/upregulation might also be responsible [211,212]. For GLP-1 independent action of DPP-4 inhibition on reduction of oxidative stress, it has been proposed that DPP-4 is an adenosine deaminase (ADA)-binding protein and regulates the subcellular localization and activity of this enzyme, which has known immunomodulatory functions [216,217]. ADA activity also leads to increased inosine levels with subsequent hypoxanthine formation and thereby provides the substrate for the pro-oxidative enzyme xanthine oxidase (XO) [208]. Furthermore, several other protein targets were described for DPP-4 such as caveolin-1, kidney $\mathrm{Na}^{+} / \mathrm{H}^{+}$ion exchanger 3 , thromboxane $\mathrm{A}_{2}$ receptor, CXCR4, CXCL12 (SDF-1), fibronectin, and many more [179], most of them being involved in the regulation of inflammation. Immunomodulation by DPP-4 seems to be critical for antioxidant properties of DPP-4 inhibitors.

Since various cell types and tissues are affected by DPP-4 inhibition and also by GLP-1, it is difficult to determine which signaling pathway is predominantly responsible for reduction of oxidative stress in a specific disease model. Most of the studies that investigated the effects of DPP-4 inhibition on oxidative burst performed no experiments with genetic or pharmacological inhibition of the GLP-1 receptor. This limitation prevents a differentiation between DPP-4- and GLP-1-dependent effects. Future studies on cell-specific GLP-1 receptor knock-out animals are needed to draw a clearer picture of the complex interaction of DPP-4 and GLP-1. The following sections will focus on the antioxidant effects of DPP-4 inhibition and GLP-1 analog supplementation in atherosclerosis and sepsis.

\subsubsection{Gliptins and GLP-1 in Atherosclerosis}

As described above, cardiovascular diseases are closely linked to oxidative stress and inflammation. Endothelial function is a reliable predictor of future cardiovascular events and is directly linked to the burden of oxidative stress in the vessel wall as well as in the blood (e.g., activation state of circulating immune cells) [12]. Recent studies demonstrate that walking distance and critical limb ischemia correlate with the activation state and production of ROS of circulating leukocytes in patients with peripheral artery disease [218-220]. Impaired endothelial function leads to inadequate vasodilation and increased disposition for infiltration of inflammatory cells. There is convincing evidence that atherosclerosis can be regarded an inflammatory disease [221].

Matsubara et al. investigated the effects of the DPP-4 inhibitor sitagliptin in an animal model of atherosclerosis [192]. They used $\mathrm{ApoE}^{-/-}$mice on a high-fat diet. Sitagliptin treatment reduced atherosclerotic lesions, improved endothelial function, and reduced infiltration of $\mathrm{CD}^{+} 8^{+}$cells into the 
vascular wall. Vascular inflammation was significantly reduced by sitagliptin treatment, which was proven by reduced mRNA levels of several pro-inflammatory cytokines (IL-6, IL-1 $\beta$, and TNF- $\alpha$ ). Similar reduction of inflammation was found in cultured human monocytes. The authors also showed the anti-inflammatory effects of a GLP-1 analog (envisaged by reduced IL-6), which was additive to the beneficial effects of sitagliptin. This in vitro experiment demonstrated that the anti-inflammatory effects of DPP-4 inhibitor and GLP-1 analog were not connected to each other. Shah et al. made similar observations in $\mathrm{LDLr}^{-/}$and $\mathrm{ApoE}^{-/-}$mice by using alogliptin treatment [193]. They demonstrated nicely the reduction of chemotaxis and monocyte activation by DPP-4 inhibitor therapy in both models of atherosclerosis. A major limitation of the study is that it does not differentiate between GLP-1- and DPP-4-dependent effects [193]. Besides the beneficial effects of DPP-4 inhibition on atherosclerosis, anti-atherosclerotic effects of GLP-1 supplementation were also demonstrated in animal models. GLP-1 therapy reduced vascular inflammation and increased plaque stability [222]. Others demonstrated improved endothelial function in $\mathrm{ApoE}^{-/-}$mice [223]. Since oxidative stress, derived from inflammatory monocytes, is a major trigger for endothelial dysfunction [23], the beneficial effects of GLP-1 in this context might rely on inhibition of this cell type. This hypothesis is supported by a recent publication reporting on reduced oxidative stress in human monocytes after exendin-4 incubation [224]. Furthermore, the antioxidant capacity (superoxide dismutase activity) in these cells was increased by exendin-4, which could be blocked by the PKA inhibitor H89 [224]. Others attributed the anti-inflammatory effects of GLP-1 to the modulation of NFKB-activity via PKA-dependent signaling pathways [225]. GLP-1 supplementation and DPP-4 inhibition induce protective effects on vascular function in animal models of atherosclerosis. Both reduce vascular inflammation, a main trigger for oxidative stress in the vasculature. Since the GLP-1 receptor and DPP-4 are expressed in endothelial cells, it may be suggested that both can improve endothelial function by direct effects. Indeed, improved function of the endothelial NO synthase in response to GLP-1 analog treatment was demonstrated, followed by reduced activation of endothelial cells via the PI3 kinase/Akt-signaling pathway [226]. Likewise, an activation of the cAMP/PKA-signaling pathway but also the cGMP-signaling pathway was reported for GLP-1 analogs [227,228]. Also, for the DPP-4 inhibitor alogliptin, potent vasodilatory effects were described based on a Src-Akt-eNOS-dependent nitric oxide release [229]. Similar vasodilatory effects were described for linagliptin in an eNOS and soluble guanylyl cyclase-dependent fashion [208]. Furthermore, studies with HUVECs revealed the inhibitory effects of GLP-1 analog treatment on mRNA expression of Nox subunits gp91 an p22 $2^{\text {phox }}[230]$.

Future studies and the use of cell-specific knock-out animals (DPP-4 and GLP-1 receptor) are needed to differentiate between the DPP-4- and GLP-1-dependent effects on vascular oxidative stress and inflammation in models of atherosclerosis.

\subsubsection{Gliptins and GLP-1 in Sepsis and Chronic Inflammatory Disease}

Sepsis is an inflammatory disease that affects the whole organism. Depending on the immune status of a patient, simple pneumonia can expand to a "systemic inflammatory response syndrome" (SIRS), which is a severe, life-threatening condition. An average mortality of $40 \%$ makes it a leading cause of death in the European Union [231]. Because of antibiotic resistance, the use of invasive procedures, 
and an aging population, sepsis has become more frequent and the absence of efficient causal therapies confers high importance and priority to future research on the septic pathomechanisms but also on more promising therapeutic interventions [232].

Endotoxins (e.g., lipopolysaccharide, LPS) are responsible for the pathogenesis of sepsis in humans and animals. They are part of the outer membrane of gram-negative bacteria and trigger the pathophysiological effects (e.g., circulatory disorders). Hypotension, impaired oxygen utilization, lactic acidosis, and aggravated blood flow in the microcirculation are characteristic of sepsis, by which multiple organ failure is caused [233-235]. Previous studies (animal and human) could show a correlation between sepsis and endothelial dysfunction, in which oxidative stress and endothelium-derived mediators (e.g., NO, prostacyclin) are involved [236-238]. The oxidative burst is a key feature of neutrophils and monocytes/macrophages, which play a pivotal role in host defense. NADPH oxidase isoform 2 is generating superoxide anion radicals in response to stimuli like LPS (gram-negative bacteria) or zymosan-A (fungi). Chronic granulomatous disease (CGD) underlines the importance of Nox2-derived superoxide anion radicals for host defense. In these patients Nox2 is dysfunctional because of a genetic mutation of the gp91 ${ }^{\text {phox }}$ gene and they are highly susceptible to infections [239]. Studies on critically ill patients revealed the protective effects of antioxidant therapy with ascorbate and $\alpha$-tocopherol [240]. It reduced the risk of organ dysfunction and duration of hospitalization in these patients [240], whereas studies on other antioxidants revealed no beneficial effects [241]. The reason for these conflicting results might be that ROS formation is needed for host defense against bacteria.

A global reduction of oxidative stress in sepsis seems not to be the perfect solution to improve survival. The most promising strategy would reduce the overshooting inflammatory response in septic patients but leave the basal host defense intact. Therefore, the question is whether systemic anti-inflammatory therapy of sepsis could counteract the overshooting immune response and might improve survival. The CORTICUS trial investigated whether hydrocortisone application, as a general suppressor of inflammation, might improve survival in septic patients. In this trial no significant improvement of survival in patients suffering from septic shock was found [242]. Furthermore, statins have anti-inflammatory properties and a recent trial tested the use of rosuvastatin in patients suffering from acute respiratory distress syndrome (ARDS). The results were disappointing and statin therapy failed to improve clinical outcome [243].

The immunomodulatory actions of DPP-4 inhibitors and GLP-1 analogs have already been discussed in general and for models of atherosclerosis. Our group investigated the anti-inflammatory and antioxidant effects of DPP-4 inhibition and GLP-1 supplementation in models of endotoxemia. For induction of endotoxemia, the LPS injection model $(10 \mathrm{mg} / \mathrm{kg})$ was used, whereas a higher dose of LPS (17 mg/kg) was used to induce partial mortality. In a first study, we were able to show that endothelial dysfunction was severely impaired in endotoxemic rats [208]. This finding was associated with increased oxidative stress in whole blood, vessel walls, and hearts of the animals. Oral treatment with the DPP-4 inhibitor linagliptin strongly improved endothelial function and accordingly reduced oxidative stress levels. Interestingly, the reduced oxidative stress in the vascular wall was accompanied by less infiltration of $\mathrm{CD} 1 \mathrm{~b}^{+}$cells and reduced myeloperoxidase protein expression. Our results revealed two different mechanisms for reduced oxidative stress under endotoxemic conditions in the vascular wall: (1) linagliptin treatment prevents expression of leukocyte adhesion molecules like 
vascular adhesion molecule-1 (VCAM-1) and thereby reduces endothelial cell activation; and (2) linagliptin directly reduces LPS-induced activation of polymorphonuclear neutrophils (PMN), which was reflected by attenuated adhesion to endothelial cells and oxidative burst. In summary, DPP-4 inhibition reduces the inflammatory state of circulating leukocytes as well as the pro-inflammatory phenotype of the vascular wall and improves the function of endothelial cells, all of which ameliorates vascular function under endotoxemic conditions (Figure 2).

\section{Improvement by DPP-4 Inhibitor Linagliptin}

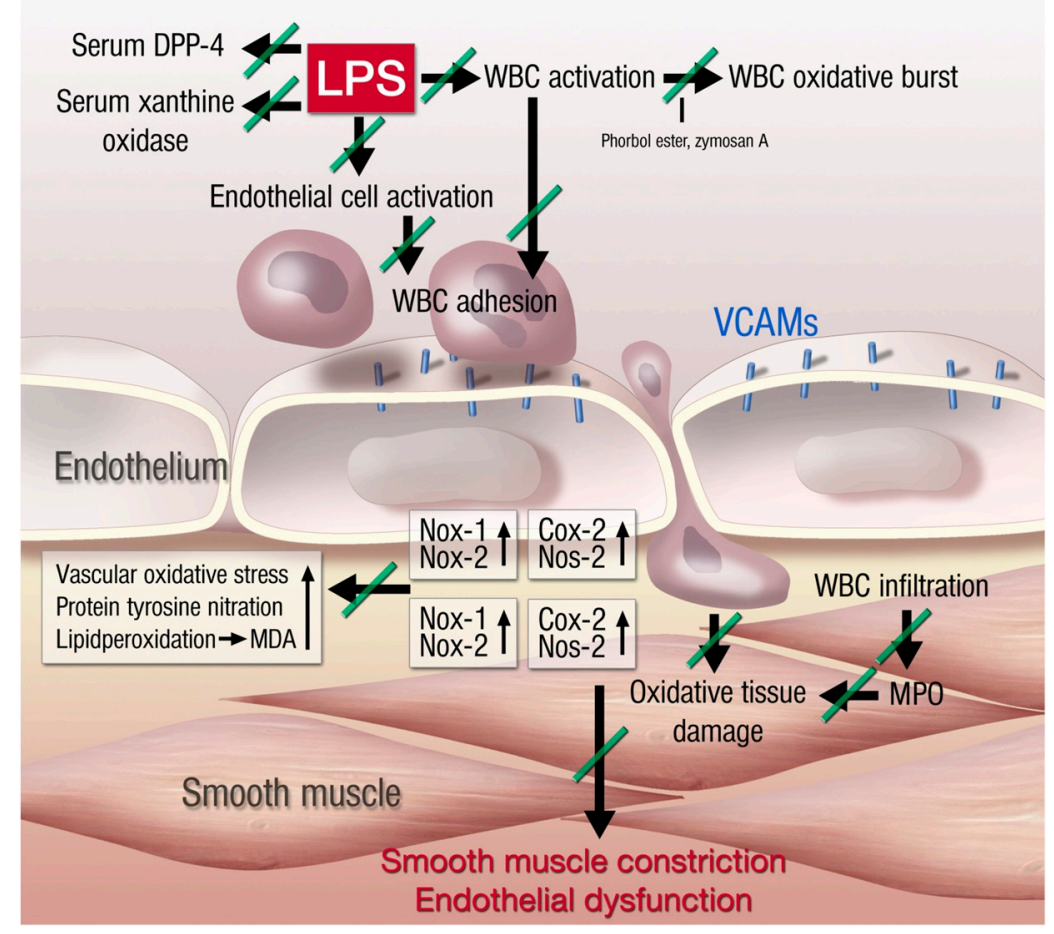

Figure 2. Proposed mechanisms of lipopolysaccharide (LPS)-induced vascular dysfunction and improvement by linagliptin therapy. LPS treatment activates white blood cells (WBC, envisaged by increased oxidative burst), increases serum levels of xanthine oxidase (XO), increases DPP-4 serum activity, and activates vascular cells (detected by expression of endothelial adhesion molecules and inducible cyclooxygenase (Cox-20). This leads to the infiltration of WBC to the vascular wall (detected by aortic FACS analysis for myelomonocytic cells, inducible nitric oxide synthase (Nos-2), Nox2, and myeloperoxidase (MPO) expression) and oxidative damage of the vasculature (Nox1 expression, ROS formation, 3-nitrotyrosine levels, and lipid peroxidation by malondialdehyde (MDA)). Finally, the tissue damage results in smooth muscle constriction and endothelial dysfunction. The green lines on the arrows define the inhibitory effects of linagliptin on septic complications. Adapted from [208]. With permission by Oxford University Press. Copyright (C) 2012, Oxford University Press.

These promising results encouraged us to investigate the impact of DPP-4 inhibition and GLP-1 supplementation on the survival of endotoxemic mice [207]. Pre- as well as post-treatment with linagliptin and the GLP-1 analog liraglutide improved survival of endotoxemic animals significantly (Figure 3A). As a proof of concept, we tested the survival of LPS-treated DPP- $4^{-/}$mice and found that 
these mice are also protected from endotoxic shock-dependent death [207]. $\mathrm{Ku}$ et al. found similar results in DPP $-4^{-/}$rats and postulated that increased GLP-1 levels are responsible for the improved survival [244]. In line with these murine data, the oxidative burst in whole blood of LPS-treated rats was significantly increased and normalized by DPP-4 inhibition and GLP-1 supplementation (Figure 3B). In accordance with this observation, the nitrosyl-iron hemoglobin (Hb-NO) signal was measured by electron spin resonance (EPR) spectroscopy in whole blood as a direct read-out for increased iNOS activity in LPS-treated animals, which was increased in endotoxemic rats and normalized by linagliptin and liraglutide therapy (Figure 3C). As a marker of vascular oxidative stress, the dihydoethidium fluorescence signal was increased in the vascular wall of LPS-treated rats and normalized by linagliptin and liraglutide treatment (Figure 3D). In summary, these data nicely show the anti-inflammatory and antioxidant potential of DPP-4 inhibitors and GLP-1 analogs, but also reveal substantial differences between the different DPP-4 inhibiting drugs that might be related to their binding affinity and specific location in the active site of DPP-4 [207,208].

A known adverse side effect of DPP-4 inhibition in humans is an increased risk for infections like nasopharygitis (risk ratio, $1.2(95 \% \mathrm{CI}, 1.0-1.4))$ or urinary tract infection (risk ratio $1.5(95 \% \mathrm{CI}$, 1.0-2.2)). These results from a meta-analysis reflect the abovementioned immunomodulatory effects of DPP-4 inhibition [245]. Furthermore, the GLP-1 analog exendin-4 reduced inflammation in a non-alcoholic steatohepatitis (NASH) animal model by decreasing the infiltration of macrophages $\left(\mathrm{CD}^{+} 8^{+}, \mathrm{F} 4 / 80^{+}\right)$[246]. Sitagliptin improved inflammation and fibrosis in methionine/choline-deficient diet-induced steatohepatitis [247]. NASH is a liver inflammatory disease, sharing several features with atherosclerosis [248]. Besides atherosclerosis, sepsis, and NASH, DPP-4 inhibitors and GLP-1 analogs exert immunomodulatory effects in various models of chronic inflammatory diseases such as colitis [249], asthma [250], chronic obstructive lung disease (COPD) [251], and rheumatoid arthritis [252].

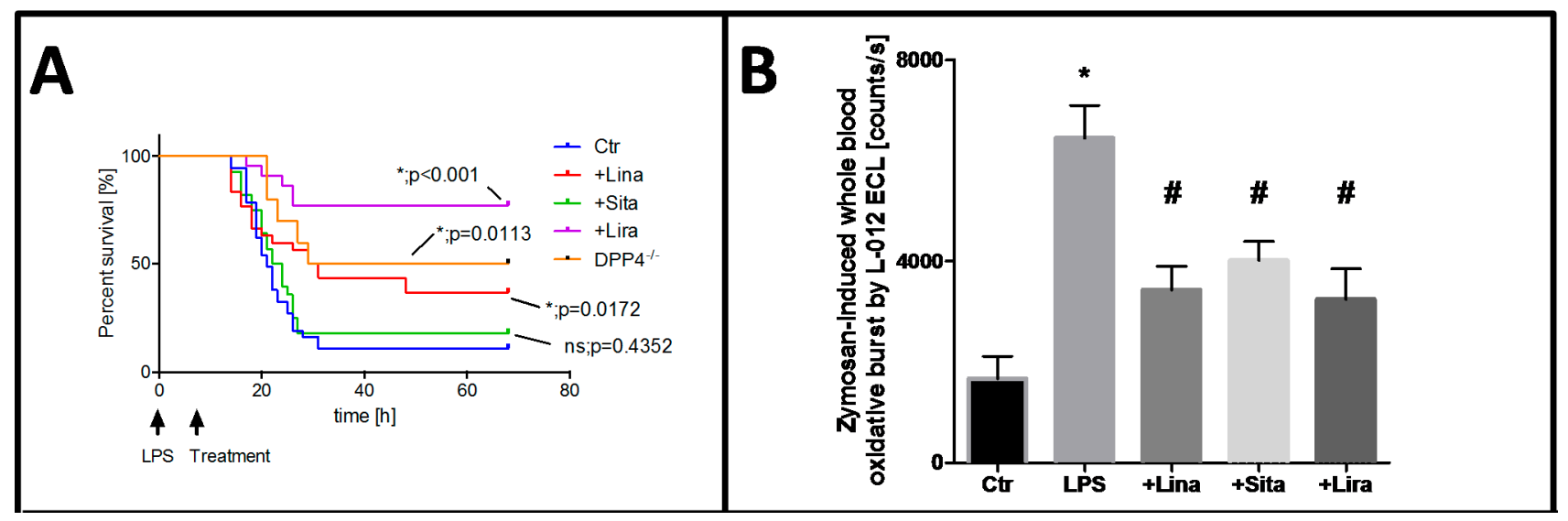

Figure 3. Cont. 


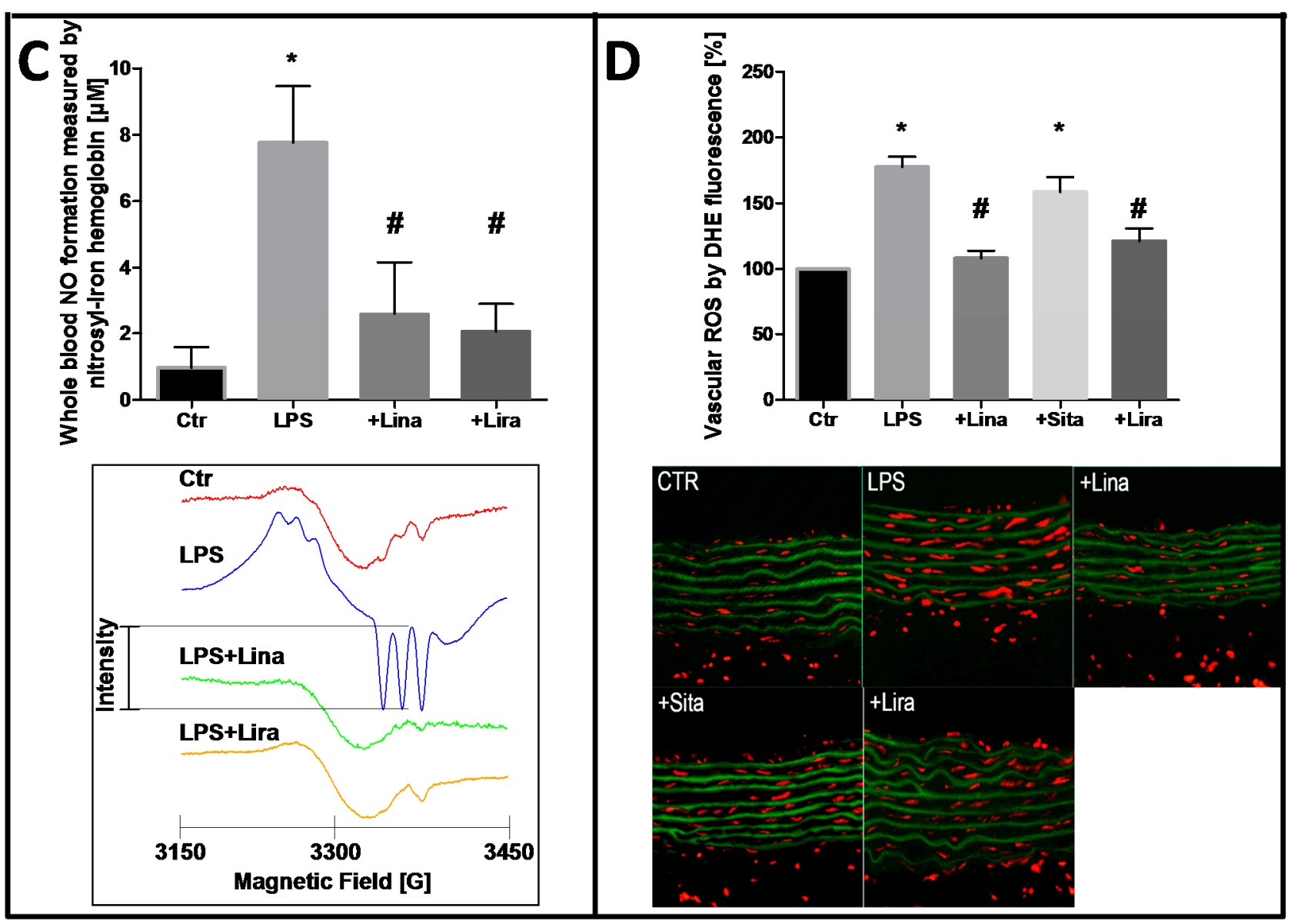

Figure 3. Protective effects of dipeptidyl peptidase-4 inhibition and glucagon-like peptide-1 analog supplementation in an animal model of LPS-induced endotoxemia. (A) Survival of animals was recorded and interpreted by Kaplan-Meier curves; (B) Whole blood oxidative burst upon stimulation with the fungal endotoxin zymosan A was measured by chemiluminescence using the luminol analog L-012; (C) iNOS-derived nitric oxide was determined in whole blood by measurement of nitrosyl-iron hemoglobin by electron paramagnetic resonance spectroscopy; (D) Vascular ROS formation was measured in aortic cryo-sections by dehydrothidium (DHE)-dependent oxidative fluorescence microtopography. Data are mean \pm SEM of experiments with 19-36 mice (A) or at least three rats per group (B-D). ${ }^{*} p<0.05$ vs. Ctr; ${ }^{\#} p<0.05$ vs. LPS. Adapted from [207]. With permission by Springer-Verlag Berlin Heidelberg. Copyright (C) 2015, Springer.

\section{Immunomodulation as a Therapeutic Strategy}

As already outlined above, inflammation represents an independent risk factor for the development of cardiovascular disease. C-reactive protein (CRP) is an acute phase protein and indicates inflammatory processes. According to the PROVE IT-TIMI 22 trial of patients with acute coronary syndrome after initiation of statin therapy, the risk of recurrent myocardial infarction or coronary death was significantly elevated in patients with a high hsCPR $(>2 \mathrm{mg} / \mathrm{L})$ compared to patients with low hsCPR levels [253]. The cytokine IL-17 was demonstrated to induce death of human endothelial cells, contributing to plaque destabilization and acute coronary syndrome by disruption of the blood-brain-barrier 
and activation of NADPH oxidase in brain endothelial cells [254,255]. These adverse effects were suppressed by administration of an IL-17A blocking antibody or by antioxidant therapy [255]. IL-17 induces endothelial cell activation, expression of endothelial adhesion molecules, followed by adhesion and infiltration of neutrophils [256], providing the rational for beneficial effects of therapy with a soluble TNF- $\alpha$ receptor antibody (etanercept) on angiotensin-II induced vascular superoxide production and hypertension [257,258]. The immunosuppressive drug methotrexate (MTX) is used in treatment of cancer and autoimmune disease. Rheumatoid arthritis patients suffer from chronic inflammation and have an increased risk for cardiovascular events. A meta-analysis revealed the antirheumatic drug to be protective against cardiovascular disease in patients with chronic inflammation [259]. Studies on myocardial infarction in dogs showed reduced infarction size by methotrexate treatment [260]. Based on these interesting results, the ongoing TETHYS trial, which investigates the effects of MTX therapy on myocardial infarction with ST-segment elevation, was initiated [261]. An additional clinical trial, which faces the effect of immunosuppression by MTX on the cardiovascular system, is the ongoing CIRT trial (Cardiovascular Inflammation Reduction trial). Patients with myocardial infarction and either type 2 diabetes mellitus or metabolic syndrome will be treated with low-dose MTX or a placebo [262]. Another target currently under investigation for immunomodulation in cardiovascular disease is IL-1 $\beta$. Animal studies revealed that blockade of IL- $1 \beta$ improves endothelial regrowth, reduces neointima formation, and thereby prevents restenosis following carotid denudation [263]. Furthermore, it ameliorates cardiac remodeling and reduces cardiomyocyte apoptosis after experimental acute myocardial infarction [264]. The ongoing CANTOS trial examines the cardiovascular outcome after blockade of IL-1 $\beta$ by canakinumab in post myocardial infarction patients [265]. There is convincing evidence for a contribution of inflammation to cardiovascular disease and immunomodulation is a promising new therapeutic approach to treat cardiovascular disease. Nevertheless, it is challenging to find a specific target and tool for modulating the inflammatory cascade. The ongoing clinical trials will provide more answers for these questions.

\section{Conclusions}

Endothelial dysfunction is an early hallmark of most cardiovascular disease in general [266] and coronary heart disease in particular [13], as well as related future cardiovascular events. Oxidative stress is associated with cardiovascular disease $[1,2]$ but also represents a prognostic marker of future cardiovascular events [12]. Therefore, oxidative stress must be considered a trigger of cardiovascular events; it probably contributes to the progression of cardiovascular disease and represents an attractive target for its therapy [267]. According to more recent data, there is a close correlation between oxidative stress and inflammation in the vasculature [8,28,218,268], making both of them independent triggers/risk factors for the progression of cardiovascular disease and future cardiovascular events $[12,36]$. Since large clinical trials on chronic oral, systemic, unspecific antioxidant therapy failed to display beneficial effects on cardiovascular events [269], the use of source and cell (organelle)-specific compounds or activators of intrinsic antioxidant systems represents a more promising strategy [122]. Another attractive attempt might be the exploitation of the antioxidant and anti-inflammatory properties of established cardiovascular drugs [5]. Screening for candidates with potent anti-inflammatory effects could represent important additional criteria for the development of 
cardiovascular drugs in the future. Comparison of drugs with similar primary effects (e.g., blood pressure lowering) but with or without pleiotropic anti-inflammatory and antioxidant effects will allow us to study the importance of these pleiotropic effects. Also, prescreening of patients for markers of inflammation and/or oxidative stress will help us to develop or find the most efficient drug or drug combination for the treatment of the patients in an individual way (in the sense of personalized medicine).

The results obtained with GLP-1 supplementation and DPP-4 inhibition in models of endotoxemia are quite promising, but they remind us of the enthusiasm about statins as a new treatment strategy in sepsis and their failure in large clinical trials [270]. Animal trials and small clinical trials showed convincing evidence for a mortality reduction by statin therapy, which also relied on immunomodulatory effects [271]. Unfortunately, these results could not be reproduced in a large multi-center trial [243] and meta-analysis revealed no improvement of survival [272]. More research is needed to better characterize the antioxidant and anti-inflammatory effects of DPP-4 inhibition and GLP-1 supplementation in the pathogenesis of sepsis. Studies in different models of sepsis (i.e., acute respiratory response syndrome or cecal ligation and puncture) and small clinical trials could shed light on this promising field of sepsis research in the future.

\section{Acknowledgments}

We thank Thilo Weckmüller and Margot Neuser for expert graphical assistance. The present work was supported by vascular biology research grants from Boehringer Ingelheim Pharma GmbH \& Co. KG, Mainzer Herz Stiftung, and the Center for Translational Vascular Biology (CTVB) (to Andreas Daiber and Thomas Münzel). Sebastian Steven holds a Virchow Fellowship from the Center of Thrombosis and Hemostasis (Mainz, Germany), funded by the Federal Ministry of Education and Research (BMBF 01EO1003). Andreas Daiber and Sebastian Steven were supported by the European Cooperation in Science and Technology (COST Action BM1203/EU-ROS).

\section{Author Contributions}

All authors contributed equally to this work. Sebastian Steven and Andreas Daiber drafted the manuscript. Thomas Münzel and Andreas Daiber made critical revisions.

\section{Conflicts of Interest}

The authors declare no conflict of interest.

\section{References}

1. Griendling, K.K.; FitzGerald, G.A. Oxidative stress and cardiovascular injury: Part I: Basic mechanisms and in vivo monitoring of ROS. Circulation 2003, 108, 1912-1916.

2. Griendling, K.K.; FitzGerald, G.A. Oxidative stress and cardiovascular injury: Part II: Animal and human studies. Circulation 2003, 108, 2034-2040.

3. Sies, H. Oxidative stress: A concept in redox biology and medicine. Redox Biol. 2015, 4, 180-183.

4. Gori, T.; Munzel, T. Oxidative stress and endothelial dysfunction: Therapeutic implications. Ann. Med. 2011, 43, 259-272. 
5. Chen, A.F.; Chen, D.D.; Daiber, A.; Faraci, F.M.; Li, H.; Rembold, C.M.; Laher, I. Free radical biology of the cardiovascular system. Clin. Sci. 2012, 123, 73-91.

6. Schulz, E.; Wenzel, P.; Munzel, T.; Daiber, A. Mitochondrial redox signaling: Interaction of mitochondrial reactive oxygen species with other sources of oxidative stress. Antioxid. Redox Signal. 2014, 20, 308-324.

7. Daiber, A.; Oelze, M.; Daub, S.; Steven, S.; Schuff, A.; Kroller-Schon, S.; Hausding, M.; Wenzel, P.; Schulz, E.; Gori, T.; et al. Vascular redox signaling, redox switches in endothelial nitric oxide synthase and endothelial dysfunction. In Systems Biology of Free Radicals and Antioxidants; Laher, I., Ed.; Springer-Verlag: Berlin Heidelberg, Germany, 2014; pp. 1177-1211.

8. Karbach, S.; Wenzel, P.; Waisman, A.; Munzel, T.; Daiber, A.E. eNOS uncoupling in cardiovascular diseases - The role of oxidative stress and inflammation. Curr. Pharm. Des. 2014, 20, 3579-3594.

9. Harrison, D.G.; Guzik, T.J.; Lob, H.E.; Madhur, M.S.; Marvar, P.J.; Thabet, S.R.; Vinh, A.; Weyand, C.M. Inflammation, immunity, and hypertension. Hypertension 2011, 57, 132-140.

10. Forstermann, U.; Munzel, T. Endothelial nitric oxide synthase in vascular disease: From marvel to menace. Circulation 2006, 113, 1708-1714.

11. Munzel, T.; Daiber, A.; Ullrich, V.; Mulsch, A. Vascular consequences of endothelial nitric oxide synthase uncoupling for the activity and expression of the soluble guanylyl cyclase and the cgmp-dependent protein kinase. Arterioscler. Thromb. Vasc. Biol. 2005, 25, 1551-1557.

12. Heitzer, T.; Schlinzig, T.; Krohn, K.; Meinertz, T.; Munzel, T. Endothelial dysfunction, oxidative stress, and risk of cardiovascular events in patients with coronary artery disease. Circulation 2001, 104, 2673-2678.

13. Schachinger, V.; Britten, M.B.; Zeiher, A.M. Prognostic impact of coronary vasodilator dysfunction on adverse long-term outcome of coronary heart disease. Circulation 2000, 101, 1899-1906.

14. Lin, C.P.; Lin, F.Y.; Huang, P.H.; Chen, Y.L.; Chen, W.C.; Chen, H.Y.; Huang, Y.C.; Liao, W.L.; Huang, H.C.; Liu, P.L.; et al. Endothelial progenitor cell dysfunction in cardiovascular diseases: Role of reactive oxygen species and inflammation. BioMed Res. Int. 2013, 2013, 845037.

15. Assmus, B.; Leistner, D.M.; Schachinger, V.; Erbs, S.; Elsasser, A.; Haberbosch, W.; Hambrecht, R.; Sedding, D.; Yu, J.; Corti, R.; et al. Long-term clinical outcome after intracoronary application of bone marrow-derived mononuclear cells for acute myocardial infarction: Migratory capacity of administered cells determines event-free survival. Eur. Heart J. 2014, 35, 1275-1283.

16. Schachinger, V.; Erbs, S.; Elsasser, A.; Haberbosch, W.; Hambrecht, R.; Holschermann, H.; $\mathrm{Yu}$, J.; Corti, R.; Mathey, D.G.; Hamm, C.W.; et al. Intracoronary bone marrow-derived progenitor cells in acute myocardial infarction. N. Engl. J. Med. 2006, 355, 1210-1221.

17. Ohara, Y.; Peterson, T.E.; Harrison, D.G. Hypercholesterolemia increases endothelial superoxide anion production. J. Clin. Investig. 1993, 91, 2546-2551.

18. Harrison, D.G.; Ohara, Y. Physiologic consequences of increased vascular oxidant stresses in hypercholesterolemia and atherosclerosis: Implications for impaired vasomotion. Am. J. Cardiol. 1995, 75, 75B-81B. 
19. Daiber, A. Redox signaling (cross-talk) from and to mitochondria involves mitochondrial pores and reactive oxygen species. Biochim. Biophys. Acta. 2010, 1797, 897-906.

20. Zorov, D.B.; Juhaszova, M.; Sollott, S.J. Mitochondrial reactive oxygen species (ROS) and ROS-induced ROS release. Physiol. Rev. 2014, 94, 909-950.

21. Cave, A.C.; Brewer, A.C.; Narayanapanicker, A.; Ray, R.; Grieve, D.J.; Walker, S.; Shah, A.M. NADPH oxidases in cardiovascular health and disease. Antioxid. Redox Signal. 2006, 8, 691-728.

22. Guzik, T.J.; Hoch, N.E.; Brown, K.A.; McCann, L.A.; Rahman, A.; Dikalov, S.; Goronzy, J.; Weyand, C.; Harrison, D.G. Role of the $\mathrm{T}$ cell in the genesis of angiotensin II induced hypertension and vascular dysfunction. J. Exp. Med. 2007, 204, 2449-2460.

23. Wenzel, P.; Knorr, M.; Kossmann, S.; Stratmann, J.; Hausding, M.; Schuhmacher, S.; Karbach, S.H.; Schwenk, M.; Yogev, N.; Schulz, E.; et al. Lysozyme M-positive monocytes mediate angiotensin II-induced arterial hypertension and vascular dysfunction. Circulation 2011, 124, 1370-1381.

24. Bulua, A.C.; Simon, A.; Maddipati, R.; Pelletier, M.; Park, H.; Kim, K.Y.; Sack, M.N.; Kastner, D.L.; Siegel, R.M. Mitochondrial reactive oxygen species promote production of proinflammatory cytokines and are elevated in TNFR1-associated periodic syndrome (TRAPS). J. Exp. Med. 2011, 208, 519-533.

25. West, A.P.; Brodsky, I.E.; Rahner, C.; Woo, D.K.; Erdjument-Bromage, H.; Tempst, P.; Walsh, M.C.; Choi, Y.; Shadel, G.S.; Ghosh, S. Tlr signalling augments macrophage bactericidal activity through mitochondrial ROS. Nature 2011, 472, 476-480.

26. Zhou, R.; Yazdi, A.S.; Menu, P.; Tschopp, J. A role for mitochondria in NLRP3 inflammasome activation. Nature 2011, 469, 221-225.

27. Mittal, M.; Siddiqui, M.R.; Tran, K.; Reddy, S.P.; Malik, A.B. Reactive oxygen species in inflammation and tissue injury. Antioxid. Redox Signal. 2014, 20, 1126-1167.

28. El Assar, M.; Angulo, J.; Rodriguez-Manas, L. Oxidative stress and vascular inflammation in aging. Free Radic. Biol. Med. 2013, 65, 380-401.

29. Mikhed, Y.; Daiber, A.; Steven, S. Mitochondrial oxidative stress, mitochondrial DNA damage and their role in age-related vascular dysfunction. Int. J. Mol. Sci. 2015, 16, 15918-15953.

30. Kroller-Schon, S.; Steven, S.; Kossmann, S.; Scholz, A.; Daub, S.; Oelze, M.; Xia, N.; Hausding, M.; Mikhed, Y.; Zinssius, E.; et al. Molecular mechanisms of the crosstalk between mitochondria and NADPH oxidase through reactive oxygen species-studies in white blood cells and in animal models. Antioxid. Redox Signal. 2014, 20, 247-266.

31. Herrera, J.; Ferrebuz, A.; MacGregor, E.G.; Rodriguez-Iturbe, B. Mycophenolate mofetil treatment improves hypertension in patients with psoriasis and rheumatoid arthritis. J. Am. Soc. Nephrol. 2006, 17, S218-S225.

32. Soltesz, P.; Kerekes, G.; Der, H.; Szucs, G.; Szanto, S.; Kiss, E.; Bodolay, E.; Zeher, M.; Timar, O.; Szodoray, P.; et al. Comparative assessment of vascular function in autoimmune rheumatic diseases: Considerations of prevention and treatment. Autoimmun. Rev. 2011, 10, 416-425.

33. Murdaca, G.; Colombo, B.M.; Cagnati, P.; Gulli, R.; Spano, F.; Puppo, F. Endothelial dysfunction in rheumatic autoimmune diseases. Atherosclerosis 2012, 224, 309-317.

34. Vena, G.A.; Vestita, M.; Cassano, N. Psoriasis and cardiovascular disease. Dermatol. Ther. 2010, 23, 144-151. 
35. Hak, A.E.; Karlson, E.W.; Feskanich, D.; Stampfer, M.J.; Costenbader, K.H. Systemic lupus erythematosus and the risk of cardiovascular disease: Results from the nurses' health study. Arthritis Rheum. 2009, 61, 1396-1402.

36. Mehta, N.N.; Azfar, R.S.; Shin, D.B.; Neimann, A.L.; Troxel, A.B.; Gelfand, J.M. Patients with severe psoriasis are at increased risk of cardiovascular mortality: Cohort study using the general practice research database. Eur. Heart J. 2010, 31, 1000-1006.

37. Peters, M.J.; Symmons, D.P.; McCarey, D.; Dijkmans, B.A.; Nicola, P.; Kvien, T.K.; McInnes, I.B.; Haentzschel, H.; Gonzalez-Gay, M.A.; Provan, S.; et al. Eular evidence-based recommendations for cardiovascular risk management in patients with rheumatoid arthritis and other forms of inflammatory arthritis. Ann. Rheum. Dis. 2010, 69, 325-331.

38. Sodergren, A.; Karp, K.; Boman, K.; Eriksson, C.; Lundstrom, E.; Smedby, T.; Soderlund, L.; Rantapaa-Dahlqvist, S.; Wallberg-Jonsson, S. Atherosclerosis in early rheumatoid arthritis: Very early endothelial activation and rapid progression of intima media thickness. Arthritis Res. Ther. 2010, 12, R158.

39. Balci, D.D.; Balci, A.; Karazincir, S.; Ucar, E.; Iyigun, U.; Yalcin, F.; Seyfeli, E.; Inandi, T.; Egilmez, E. Increased carotid artery intima-media thickness and impaired endothelial function in psoriasis. J. Eur. Acad. Dermatol. Venereol. 2009, 23, 1-6.

40. Di Cesare, A.; di Meglio, P.; Nestle, F.O. The IL-23/Th17 axis in the immunopathogenesis of psoriasis. J. Investig. Dermatol. 2009, 129, 1339-1350.

41. Leonardi, C.; Matheson, R.; Zachariae, C.; Cameron, G.; Li, L.; Edson-Heredia, E.; Braun, D.; Banerjee, S. Anti-interleukin-17 monoclonal antibody ixekizumab in chronic plaque psoriasis. N. Engl. J. Med. 2012, 366, 1190-1199.

42. Papp, K.A.; Leonardi, C.; Menter, A.; Ortonne, J.P.; Krueger, J.G.; Kricorian, G.; Aras, G.; Li, J.; Russell, C.B.; Thompson, E.H.; et al. Brodalumab, an anti-interleukin-17-receptor antibody for psoriasis. N. Engl. J. Med. 2012, 366, 1181-1189.

43. Crispin, J.C.; Tsokos, G.C. IL-17 in systemic lupus erythematosus. J. Biomed. Biotechnol. 2010, 2010, 943254.

44. Choy, E. Understanding the dynamics: Pathways involved in the pathogenesis of rheumatoid arthritis. Rheumatology (Oxford) 2012, 51 (Suppl. 5), v3-v11.

45. Pasceri, V.; Yeh, E.T. A tale of two diseases: Atherosclerosis and rheumatoid arthritis. Circulation 1999, 100, 2124-2126.

46. Sesso, H.D.; Christen, W.G.; Bubes, V.; Smith, J.P.; MacFadyen, J.; Schvartz, M.; Manson, J.E.; Glynn, R.J.; Buring, J.E.; Gaziano, J.M. Multivitamins in the prevention of cardiovascular disease in men: The physicians' health study II randomized controlled trial. JAMA 2012, 308, 1751-1760.

47. Lonn, E.; Bosch, J.; Yusuf, S.; Sheridan, P.; Pogue, J.; Arnold, J.M.; Ross, C.; Arnold, A.; Sleight, P.; Probstfield, J.; et al. Effects of long-term vitamin e supplementation on cardiovascular events and cancer: A randomized controlled trial. JAMA 2005, 293, 1338-1347.

48. Muntwyler, J.; Hennekens, C.H.; Manson, J.E.; Buring, J.E.; Gaziano, J.M. Vitamin supplement use in a low-risk population of us male physicians and subsequent cardiovascular mortality. Arch. Intern. Med. 2002, 162, 1472-1476. 
49. Mann, J.F.; Lonn, E.M.; Yi, Q.; Gerstein, H.C.; Hoogwerf, B.J.; Pogue, J.; Bosch, J.; Dagenais, G.R.; Yusuf, S. Effects of vitamin e on cardiovascular outcomes in people with mild-to-moderate renal insufficiency: Results of the hope study. Kidney Int. 2004, 65, 1375-1380.

50. Yusuf, S.; Dagenais, G.; Pogue, J.; Bosch, J.; Sleight, P. Vitamin e supplementation and cardiovascular events in high-risk patients. The heart outcomes prevention evaluation study investigators. N. Engl. J. Med. 2000, 342, 154-160.

51. Schmidt, H.H.; Stocker, R.; Vollbracht, C.; Paulsen, G.; Riley, D.P.; Daiber, A.; Cuadrado, A. Antioxidants in translational medicine. Antioxid. Redox Signal. 2015, doi:10.1089/ars.2015.6393.

52. Lee, D.H.; Folsom, A.R.; Harnack, L.; Halliwell, B.; Jacobs, D.R., Jr. Does supplemental vitamin $\mathrm{C}$ increase cardiovascular disease risk in women with diabetes? Am. J. Clin. Nutr. 2004, 80, 1194-1200.

53. Shuaib, A.; Lees, K.R.; Lyden, P.; Grotta, J.; Davalos, A.; Davis, S.M.; Diener, H.C.; Ashwood, T.; Wasiewski, W.W.; Emeribe, U.; et al. Nxy-059 for the treatment of acute ischemic stroke. N. Engl. J. Med. 2007, 357, 562-571.

54. Bjelakovic, G.; Nikolova, D.; Gluud, L.L.; Simonetti, R.G.; Gluud, C. Mortality in randomized trials of antioxidant supplements for primary and secondary prevention: Systematic review and meta-analysis. JAMA 2007, 297, 842-857.

55. Bjelakovic, G.; Nikolova, D.; Simonetti, R.G.; Gluud, C. Antioxidant supplements for prevention of gastrointestinal cancers: A systematic review and meta-analysis. Lancet 2004, 364, 1219-1228.

56. Harris, H.R.; Orsini, N.; Wolk, A. Vitamin C and survival among women with breast cancer: A meta-analysis. Eur. J. Cancer 2014, 50, 1223-1231.

57. Ashor, A.W.; Lara, J.; Mathers, J.C.; Siervo, M. Effect of vitamin C on endothelial function in health and disease: A systematic review and meta-analysis of randomised controlled trials. Atherosclerosis 2014, 235, 9-20.

58. Heitzer, T.; Finckh, B.; Albers, S.; Krohn, K.; Kohlschutter, A.; Meinertz, T. Beneficial effects of $\alpha$-lipoic acid and ascorbic acid on endothelium-dependent, nitric oxide-mediated vasodilation in diabetic patients: Relation to parameters of oxidative stress. Free Radic. Biol. Med. 2001, 31, 53-61.

59. Heitzer, T.; Brockhoff, C.; Mayer, B.; Warnholtz, A.; Mollnau, H.; Henne, S.; Meinertz, T.; Munzel, T. Tetrahydrobiopterin improves endothelium-dependent vasodilation in chronic smokers : Evidence for a dysfunctional nitric oxide synthase. Circ. Res. 2000, 86, E36-E41.

60. Heitzer, T.; Just, H.; Munzel, T. Antioxidant vitamin C improves endothelial dysfunction in chronic smokers. Circulation 1996, 94, 6-9.

61. Levine, M.; Rumsey, S.C.; Daruwala, R.; Park, J.B.; Wang, Y. Criteria and recommendations for vitamin C intake. JAMA 1999, 281, 1415-1423.

62. Deng, Y.B.; Li, T.L.; Xiang, H.J.; Chang, Q.; Li, C.L. Impaired endothelial function in the brachial artery after kawasaki disease and the effects of intravenous administration of vitamin $\mathrm{C}$. Pediatr. Infect. Dis. J. 2003, 22, 34-39.

63. Schaufele, T.G.; Schlaich, M.P.; Delles, C.; Klingbeil, A.U.; Fleischmann, E.H.; Schmieder, R.E. Impaired basal no activity in patients with glomerular disease and the influence of oxidative stress. Kidney Int. 2006, 70, 1177-1181. 
64. Solzbach, U.; Hornig, B.; Jeserich, M.; Just, H. Vitamin C improves endothelial dysfunction of epicardial coronary arteries in hypertensive patients. Circulation 1997, 96, 1513-1519.

65. Hernandez-Guerra, M.; Garcia-Pagan, J.C.; Turnes, J.; Bellot, P.; Deulofeu, R.; Abraldes, J.G.; Bosch, J. Ascorbic acid improves the intrahepatic endothelial dysfunction of patients with cirrhosis and portal hypertension. Hepatology 2006, 43, 485-491.

66. Hagel, A.F.; Layritz, C.M.; Hagel, W.H.; Hagel, H.J.; Hagel, E.; Dauth, W.; Kressel, J.; Regnet, T.; Rosenberg, A.; Neurath, M.F.; et al. Intravenous infusion of ascorbic acid decreases serum histamine concentrations in patients with allergic and non-allergic diseases. Naunyn Schmiedebergs Arch. Pharmacol. 2013, 386, 789-793.

67. Kang, H.S.; Park, J.J.; Ahn, S.K.; Hur, D.G.; Kim, H.Y. Effect of high dose intravenous vitamin $\mathrm{C}$ on idiopathic sudden sensorineural hearing loss: A prospective single-blind randomized controlled trial. Eur. Arch. Otorhinolaryngol. 2013, 270, 2631-2636.

68. Du, W.D.; Yuan, Z.R.; Sun, J.; Tang, J.X.; Cheng, A.Q.; Shen, D.M.; Huang, C.J.; Song, X.H.; $\mathrm{Yu}, \mathrm{X} . \mathrm{F}$.; Zheng, S.B. Therapeutic efficacy of high-dose vitamin $\mathrm{C}$ on acute pancreatitis and its potential mechanisms. World J. Gastroenterol. 2003, 9, 2565-2569.

69. Holick, M.F. Vitamin D deficiency. N. Engl. J. Med. 2007, 357, 266-281.

70. Harris, R.A.; Pedersen-White, J.; Guo, D.H.; Stallmann-Jorgensen, I.S.; Keeton, D.; Huang, Y.; Shah, Y.; Zhu, H.; Dong, Y. Vitamin $\mathrm{D}_{3}$ supplementation for 16 weeks improves flow-mediated dilation in overweight african-american adults. Am. J. Hypertens. 2011, 24, 557-562.

71. Sugden, J.A.; Davies, J.I.; Witham, M.D.; Morris, A.D.; Struthers, A.D. Vitamin D improves endothelial function in patients with type 2 diabetes mellitus and low vitamin D levels. Diabet. Med. 2008, 25, 320-325.

72. Pfeifer, M.; Begerow, B.; Minne, H.W.; Nachtigall, D.; Hansen, C. Effects of a short-term vitamin $\mathrm{D}_{3}$ and calcium supplementation on blood pressure and parathyroid hormone levels in elderly women. J. Clin. Endocrinol. Metab. 2001, 86, 1633-1637.

73. Kim, H.W.; Park, C.W.; Shin, Y.S.; Kim, Y.S.; Shin, S.J.; Kim, Y.S.; Choi, E.J.; Chang, Y.S.; Bang, B.K. Calcitriol regresses cardiac hypertrophy and QT dispersion in secondary hyperparathyroidism on hemodialysis. Nephron. Clin. Pract. 2006, 102, c21-29.

74. Park, C.W.; Oh, Y.S.; Shin, Y.S.; Kim, C.M.; Kim, Y.S.; Kim, S.Y.; Choi, E.J.; Chang, Y.S.; Bang, B.K. Intravenous calcitriol regresses myocardial hypertrophy in hemodialysis patients with secondary hyperparathyroidism. Am. J. Kidney Dis. 1999, 33, 73-81.

75. Bjelakovic, G.; Gluud, L.L.; Nikolova, D.; Whitfield, K.; Wetterslev, J.; Simonetti, R.G.; Bjelakovic, M.; Gluud, C. Vitamin D supplementation for prevention of mortality in adults. Cochrane Database Syst. Rev. 2014, 1, CD007470.

76. Janssen, H.C.; Samson, M.M.; Verhaar, H.J. Vitamin D deficiency, muscle function, and falls in elderly people. Am. J. Clin. Nutr. 2002, 75, 611-615.

77. Mozos, I.; Marginean, O. Links between vitamin D deficiency and cardiovascular diseases. BioMed Res. Int. 2015, 2015, 109275.

78. Stocker, R. The ambivalence of vitamin E in atherogenesis. Trends Biochem. Sci. 1999, 24, 219-223. 
79. Khaw, K.T.; Bingham, S.; Welch, A.; Luben, R.; Wareham, N.; Oakes, S.; Day, N. Relation between plasma ascorbic acid and mortality in men and women in epic-norfolk prospective study: A prospective population study. European prospective investigation into cancer and nutrition. Lancet 2001, 357, 657-663.

80. Chen, G.C.; Lu, D.B.; Pang, Z.; Liu, Q.F. Vitamin C intake, circulating vitamin C and risk of stroke: A meta-analysis of prospective studies. J. Am. Heart Assoc. 2013, 2, e000329.

81. Tveden-Nyborg, P.; Lykkesfeldt, J. Does vitamin C deficiency increase lifestyle-associated vascular disease progression? Evidence based on experimental and clinical studies. Antioxid. Redox Signal. 2013, 19, 2084-2104.

82. Ashor, A.W.; Siervo, M.; Lara, J.; Oggioni, C.; Mathers, J.C. Antioxidant vitamin supplementation reduces arterial stiffness in adults: A systematic review and meta-analysis of randomized controlled trials. J. Nutr. 2014, 144, 1594-1602.

83. Koopman, W.J.; Verkaart, S.; Visch, H.J.; van der Westhuizen, F.H.; Murphy, M.P.; van den Heuvel, L.W.; Smeitink, J.A.; Willems, P.H. Inhibition of complex I of the electron transport chain causes $\mathrm{O}_{2}^{-} \cdot-$ mediated mitochondrial outgrowth. Am. J. Physiol. Cell Physiol. 2005, 288, C1440-C1450.

84. Adlam, V.J.; Harrison, J.C.; Porteous, C.M.; James, A.M.; Smith, R.A.; Murphy, M.P.; Sammut, I.A. Targeting an antioxidant to mitochondria decreases cardiac ischemia-reperfusion injury. FASEB J. 2005, 19, 1088-1095.

85. Wiegman, C.H.; Michaeloudes, C.; Haji, G.; Narang, P.; Clarke, C.J.; Russell, K.E.; Bao, W.; Pavlidis, S.; Barnes, P.J.; Kanerva, J.; et al. Oxidative stress-induced mitochondrial dysfunction drives inflammation and airway smooth muscle remodeling in patients with chronic obstructive pulmonary disease. J. Allergy Clin. Immunol. 2015, doi:10.1016/j.jaci.2015.01.046.

86. Esplugues, J.V.; Rocha, M.; Nunez, C.; Bosca, I.; Ibiza, S.; Herance, J.R.; Ortega, A.; Serrador, J.M.; D’Ocon, P.; Victor, V.M. Complex i dysfunction and tolerance to nitroglycerin: An approach based on mitochondrial-targeted antioxidants. Circ. Res. 2006, 99, 1067-1075.

87. Graham, D.; Huynh, N.N.; Hamilton, C.A.; Beattie, E.; Smith, R.A.; Cocheme, H.M.; Murphy, M.P.; Dominiczak, A.F. Mitochondria-targeted antioxidant MitoQ 10 improves endothelial function and attenuates cardiac hypertrophy. Hypertension 2009, 54, 322-328.

88. Miquel, E.; Cassina, A.; Martinez-Palma, L.; Souza, J.M.; Bolatto, C.; Rodriguez-Bottero, S.; Logan, A.; Smith, R.A.; Murphy, M.P.; Barbeito, L.; et al. Neuroprotective effects of the mitochondria-targeted antioxidant MitoQ in a model of inherited amyotrophic lateral sclerosis. Free Radic. Biol. Med. 2014, 70, 204-213.

89. Dashdorj, A.; Jyothi, K.R.; Lim, S.; Jo, A.; Nguyen, M.N.; Ha, J.; Yoon, K.S.; Kim, H.J.; Park, J.H.; Murphy, M.P.; et al. Mitochondria-targeted antioxidant MitoQ ameliorates experimental mouse colitis by suppressing NLRP3 inflammasome-mediated inflammatory cytokines. BMC Med. 2013, 11, 178.

90. Chacko, B.K.; Reily, C.; Srivastava, A.; Johnson, M.S.; Ye, Y.; Ulasova, E.; Agarwal, A.; Zinn, K.R.; Murphy, M.P.; Kalyanaraman, B.; et al. Prevention of diabetic nephropathy in Ins2(+/) ${ }^{-}$(AkitaJ) mice by the mitochondria-targeted therapy MitoQ. Biochem. J. 2010, 432, 9-19. 
91. Dikalova, A.E.; Bikineyeva, A.T.; Budzyn, K.; Nazarewicz, R.R.; McCann, L.; Lewis, W.; Harrison, D.G.; Dikalov, S.I. Therapeutic targeting of mitochondrial superoxide in hypertension. Circ. Res. 2010, 107, 106-116.

92. Batinic-Haberle, I.; Rajic, Z.; Tovmasyan, A.; Reboucas, J.S.; Ye, X.; Leong, K.W.; Dewhirst, M.W.; Vujaskovic, Z.; Benov, L.; Spasojevic, I. Diverse functions of cationic Mn(III) $N$-substituted pyridylporphyrins, recognized as SOD mimics. Free Radic. Biol. Med. 2011, 51, 1035-1053.

93. Batinic-Haberle, I.; Tovmasyan, A.; Roberts, E.R.; Vujaskovic, Z.; Leong, K.W.; Spasojevic, I. SOD therapeutics: Latest insights into their structure-activity relationships and impact on the cellular redox-based signaling pathways. Antioxid. Redox Signal. 2014, 20, 2372-2415.

94. Smith, R.A.; Hartley, R.C.; Murphy, M.P. Mitochondria-targeted small molecule therapeutics and probes. Antioxid. Redox Signal. 2011, 15, 3021-3038.

95. Murphy, M.P. Antioxidants as therapies: Can we improve on nature? Free Radic. Biol. Med. 2014, 66, 20-23.

96. Shuvaev, V.V.; Christofidou-Solomidou, M.; Bhora, F.; Laude, K.; Cai, H.; Dikalov, S.; Arguiri, E.; Solomides, C.C.; Albelda, S.M.; Harrison, D.G.; et al. Targeted detoxification of selected reactive oxygen species in the vascular endothelium. J. Pharmacol. Exp. Ther. 2009, 331, 404-411.

97. Fernandez, C.; Hattan, C.M.; Kerns, R.J. Semi-synthetic heparin derivatives: Chemical modifications of heparin beyond chain length, sulfate substitution pattern and $N$-sulfo/ $N$-acetyl groups. Carbohydr. Res. 2006, 341, 1253-1265.

98. Kleschyov, A.L.; Sen, V.; Golubev, V.; Munnemann, K.; Hinderberger, D.; Lackner, K.J.; Weber, S.; Terekhov, M.; Schreiber, L.M.; Munzel, T. Heparin-polynitroxides: Synthesis and preliminary evaluation as cardiovascular EPR/MR imaging probes and extracellular space-targeted antioxidants. Eur. J. Med. Chem. 2012, 58, 265-271.

99. Kleschyov, A.L.; Sen, V.D. Heparin-polynitroxide derivatives: A platform for new diagnostic and therapeutic agents in cardiovascular disease? Future Med. Chem. 2013, 5, 385-388.

100. Mikhed, Y.; Gorlach, A.; Knaus, U.G.; Daiber, A. Redox regulation of genome stability by effects on gene expression, epigenetic pathways and DNA damage/repair. Redox Biol. 2015, 5, 275-289.

101. Hayes, P.; Knaus, U.G. Balancing reactive oxygen species in the epigenome: NADPH oxidases as target and perpetrator. Antioxid. Redox Signal. 2013, 18, 1937-1945.

102. Baird, A.M.; O’Byrne, K.J.; Gray, S.G. Reactive oxygen species and reactive nitrogen species in epigenetic modifications. In Systems Biology of Free Radicals and Antioxidants; Laher, I. Ed.; Springer-Verlag: Berlin Heidelberg, Germany, 2014; pp. 437-455.

103. Archer, S.L.; Marsboom, G.; Kim, G.H.; Zhang, H.J.; Toth, P.T.; Svensson, E.C.; Dyck, J.R.; Gomberg-Maitland, M.; Thebaud, B.; Husain, A.N.; et al. Epigenetic attenuation of mitochondrial superoxide dismutase 2 in pulmonary arterial hypertension: A basis for excessive cell proliferation and a new therapeutic target. Circulation 2010, 121, 2661-2671.

104. Cooper, M.P.; Keaney, J.F., Jr. Epigenetic control of angiogenesis via DNA methylation. Circulation 2011, 123, 2916-2918. 
105. Kim, G.H.; Ryan, J.J.; Archer, S.L. The role of redox signaling in epigenetics and cardiovascular disease. Antioxid. Redox Signal. 2013, 18, 1920-1936.

106. Wang, J.; Gong, L.; Tan, Y.; Hui, R.; Wang, Y. Hypertensive epigenetics: From DNA methylation to micrornas. J. Hum. Hypertens. 2015, doi:10.1038/jhh.2014.132.

107. Li, H.; Xia, N.; Forstermann, U. Cardiovascular effects and molecular targets of resveratrol. Nitric Oxide 2012, 26, 102-110.

108. Mukhopadhyay, P.; Pacher, P.; Das, D.K. Microrna signatures of resveratrol in the ischemic heart. Ann. N. Y. Acad. Sci. 2011, 1215, 109-116.

109. Farghali, H.; Kutinova Canova, N.; Lekic, N. Resveratrol and related compounds as antioxidants with an allosteric mechanism of action in epigenetic drug targets. Physiol. Res. 2013, 62, 1-13.

110. Gatz, S.A.; Wiesmuller, L. Take a break-resveratrol in action on DNA. Carcinogenesis 2008, 29, 321-332.

111. Zhou, W.; Chai, H.; Lin, P.H.; Lumsden, A.B.; Yao, Q.; Chen, C. Clinical use and molecular mechanisms of action of extract of ginkgo biloba leaves in cardiovascular diseases. Cardiovasc. Drug Rev. 2004, 22, 309-319.

112. Kleikers, P.W.; Wingler, K.; Hermans, J.J.; Diebold, I.; Altenhofer, S.; Radermacher, K.A.; Janssen, B.; Gorlach, A.; Schmidt, H.H. NADPH oxidases as a source of oxidative stress and molecular target in ischemia/reperfusion injury. Int. J. Mol. Med. 2012, 90, 1391-1406.

113. Altenhofer, S.; Kleikers, P.W.; Radermacher, K.A.; Scheurer, P.; Rob Hermans, J.J.; Schiffers, P.; Ho, H.; Wingler, K.; Schmidt, H.H. The Nox toolbox: Validating the role of NADPH oxidases in physiology and disease. Cell. Mol. Life Sci. 2012, 69, 2327-2343.

114. Radermacher, K.A.; Wingler, K.; Langhauser, F.; Altenhofer, S.; Kleikers, P.; Hermans, J.J.; Hrabe de Angelis, M.; Kleinschnitz, C.; Schmidt, H.H. Neuroprotection after stroke by targeting Nox4 as a source of oxidative stress. Antioxid. Redox Signal. 2013, 18, 1418-1427.

115. Wingler, K.; Hermans, J.J.; Schiffers, P.; Moens, A.; Paul, M.; Schmidt, H.H. Nox1, 2, 4, 5: Counting out oxidative stress. Br. J. Pharmacol. 2011, 164, 866-883.

116. Lee, B.E.; Toledo, A.H.; Anaya-Prado, R.; Roach, R.R.; Toledo-Pereyra, L.H. Allopurinol, xanthine oxidase, and cardiac ischemia. J. Investig. Med. 2009, 57, 902-909.

117. Higgins, P.; Dawson, J.; Lees, K.R.; McArthur, K.; Quinn, T.J.; Walters, M.R. Xanthine oxidase inhibition for the treatment of cardiovascular disease: A systematic review and meta-analysis. Cardiovasc. Ther. 2012, 30, 217-226.

118. Jazwa, A.; Cuadrado, A. Targeting heme oxygenase-1 for neuroprotection and neuroinflammation in neurodegenerative diseases. Curr. Drug Targets 2010, 11, 1517-1531.

119. Evgenov, O.V.; Pacher, P.; Schmidt, P.M.; Hasko, G.; Schmidt, H.H.; Stasch, J.P. NO-independent stimulators and activators of soluble guanylate cyclase: Discovery and therapeutic potential. Nat. Rev. Drug Discov. 2006, 5, 755-768.

120. Follmann, M.; Griebenow, N.; Hahn, M.G.; Hartung, I.; Mais, F.J.; Mittendorf, J.; Schafer, M.; Schirok, H.; Stasch, J.P.; Stoll, F.; et al. The chemistry and biology of soluble guanylate cyclase stimulators and activators. Angew. Chem. Int. Ed. Engl. 2013, 52, 9442-9462.

121. Schmidt, H.H.; Schmidt, P.M.; Stasch, J.P. NO- and haem-independent soluble guanylate cyclase activators. Handb. Exp. Pharmacol. 2009, 191, 309-339. 
122. Lonn, M.E.; Dennis, J.M.; Stocker, R. Actions of "antioxidants" in the protection against atherosclerosis. Free Radic. Biol. Med. 2012, 53, 863-884.

123. Drexler, H.; Hornig, B. Endothelial dysfunction in human disease. J. Mol. Cell. Cardiol. 1999, 31, 51-60.

124. Warnholtz, A.; Munzel, T. Why do antioxidants fail to provide clinical benefit? Curr. Control. Trials Cardiovasc. Med. 2000, 1, 38-40.

125. Porsti, I.; Bara, A.T.; Busse, R.; Hecker, M. Release of nitric oxide by angiotensin-(1-7) from porcine coronary endothelium: Implications for a novel angiotensin receptor. Br. J. Pharmacol. 1994, 111, 652-654.

126. Mollnau, H.; Oelze, M.; August, M.; Wendt, M.; Daiber, A.; Schulz, E.; Baldus, S.; Kleschyov, A.L.; Materne, A.; Wenzel, P.; et al. Mechanisms of increased vascular superoxide production in an experimental model of idiopathic dilated cardiomyopathy. Arterioscler. Thromb. Vasc. Biol. 2005, 25, 2554-2559.

127. Williams, H.C.; Griendling, K.K. NADPH oxidase inhibitors: New antihypertensive agents? J. Cardiovasc. Pharmacol. 2007, 50, 9-16.

128. Soehnlein, O.; Schmeisser, A.; Cicha, I.; Reiss, C.; Ulbrich, H.; Lindbom, L.; Daniel, W.G.; Garlichs, C.D. Ace inhibition lowers angiotensin-II-induced monocyte adhesion to HUVEC by reduction of p65 translocation and AT1 expression. J. Vasc. Res. 2005, 42, 399-407.

129. Caspritz, G.; Alpermann, H.G.; Schleyerbach, R. Influence of the new angiotensin converting enzyme inhibitor ramipril on several models of acute inflammation and the adjuvant arthritis in the rat. Arzneimittelforschung 1986, 36, 1605-1608.

130. Durik, M.; Seva Pessoa, B.; Roks, A.J. The renin-angiotensin system, bone marrow and progenitor cells. Clin. Sci. 2012, 123, 205-223.

131. Munzel, T.; Gori, T.; Keaney, J.F., Jr.; Maack, C.; Daiber, A. Pathophysiological role of oxidative stress in systolic and diastolic heart failure and its therapeutic implications. Eur. Heart. J. 2015, doi:10.1093/eurheartj/ehv305.

132. Takemoto, M.; Liao, J.K. Pleiotropic effects of 3-hydroxy-3-methylglutaryl coenzyme a reductase inhibitors. Arterioscler. Thromb. Vasc. Biol. 2001, 21, 1712-1719.

133. Ray, K.K.; Cannon, C.P. Pathological changes in acute coronary syndromes: The role of statin therapy in the modulation of inflammation, endothelial function and coagulation. J. Thromb. Thrombolysis 2004, 18, 89-101.

134. Patel, T.N.; Shishehbor, M.H.; Bhatt, D.L. A review of high-dose statin therapy: Targeting cholesterol and inflammation in atherosclerosis. Eur. Heart J. 2007, 28, 664-672.

135. Adam, O.; Laufs, U. Racl-mediated effects of HMG-CoA reductase inhibitors (statins) in cardiovascular disease. Antioxid. Redox Signal. 2014, 20, 1238-1250.

136. Wenzel, P.; Daiber, A.; Oelze, M.; Brandt, M.; Closs, E.; Xu, J.; Thum, T.; Bauersachs, J.; Ertl, G.; Zou, M.H.; et al. Mechanisms underlying recoupling of eNOS by HMG-CoA reductase inhibition in a rat model of streptozotocin-induced diabetes mellitus. Atherosclerosis 2008, 198, 65-76.

137. Margaritis, M.; Channon, K.M.; Antoniades, C. Statins as regulators of redox state in the vascular endothelium: Beyond lipid lowering. Antioxid. Redox Signal. 2014, 20, 1198-1215. 
138. Habeos, I.G.; Ziros, P.G.; Chartoumpekis, D.; Psyrogiannis, A.; Kyriazopoulou, V.; Papavassiliou, A.G. Simvastatin activates Keap1/Nrf2 signaling in rat liver. Int. J. Mol. Med. 2008, 86, 1279-1285.

139. Ali, F.; Zakkar, M.; Karu, K.; Lidington, E.A.; Hamdulay, S.S.; Boyle, J.J.; Zloh, M.; Bauer, A.; Haskard, D.O.; Evans, P.C.; et al. Induction of the cytoprotective enzyme heme oxygenase-1 by statins is enhanced in vascular endothelium exposed to laminar shear stress and impaired by disturbed flow. J. Biol. Chem. 2009, 284, 18882-18892.

140. Hibbert, B.; Simard, T.; Ramirez, F.D.; Pourdjabbar, A.; Raizman, J.E.; Maze, R.; Wilson, K.R.; Hawken, S.; O'Brien, E.R. The effect of statins on circulating endothelial progenitor cells in humans: A systematic review. J. Cardiovasc. Pharmacol. 2013, 62, 491-496.

141. Magee, L.A.; Abalos, E.; von Dadelszen, P.; Sibai, B.; Easterling, T.; Walkinshaw, S.; Group, C.S. How to manage hypertension in pregnancy effectively. Br. J. Clin. Pharmacol. 2011, 72, 394-401.

142. Anand, I.S.; Tam, S.W.; Rector, T.S.; Taylor, A.L.; Sabolinski, M.L.; Archambault, W.T.; Adams, K.F.; Olukotun, A.Y.; Worcel, M.; Cohn, J.N. Influence of blood pressure on the effectiveness of a fixed-dose combination of isosorbide dinitrate and hydralazine in the african-american heart failure trial. J. Am. Coll. Cardiol. 2007, 49, 32-39.

143. Taylor, A.L.; Ziesche, S.; Yancy, C.W.; Carson, P.; Ferdinand, K.; Taylor, M.; Adams, K.; Olukotun, A.Y.; Ofili, E.; Tam, S.W.; et al. Early and sustained benefit on event-free survival and heart failure hospitalization from fixed-dose combination of isosorbide dinitrate/hydralazine: Consistency across subgroups in the african-american heart failure trial. Circulation 2007, 115, 1747-1753.

144. Cohn, J.N.; Tam, S.W.; Anand, I.S.; Taylor, A.L.; Sabolinski, M.L.; Worcel, M. Isosorbide dinitrate and hydralazine in a fixed-dose combination produces further regression of left ventricular remodeling in a well-treated black population with heart failure: Results from A-HeFT. J. Card. Fail. 2007, 13, 331-339.

145. Daiber, A.; Oelze, M.; Coldewey, M.; Kaiser, K.; Huth, C.; Schildknecht, S.; Bachschmid, M.; Nazirisadeh, Y.; Ullrich, V.; Mulsch, A.; et al. Hydralazine is a powerful inhibitor of peroxynitrite formation as a possible explanation for its beneficial effects on prognosis in patients with congestive heart failure. Biochem. Biophys. Res. Commun. 2005, 338, 1865-1874.

146. Daiber, A.; Mulsch, A.; Hink, U.; Mollnau, H.; Warnholtz, A.; Oelze, M.; Munzel, T. The oxidative stress concept of nitrate tolerance and the antioxidant properties of hydralazine. Am. J. Cardiol. 2005, 96, 25i-36i.

147. Munzel, T.; Kurz, S.; Rajagopalan, S.; Thoenes, M.; Berrington, W.R.; Thompson, J.A.; Freeman, B.A.; Harrison, D.G. Hydralazine prevents nitroglycerin tolerance by inhibiting activation of a membrane-bound nadh oxidase. A new action for an old drug. J. Clin. Investig. 1996, 98, 1465-1470.

148. Sekiya, M.; Sato, M.; Funada, J.; Ohtani, T.; Akutsu, H.; Watanabe, K. Effects of the long-term administration of nicorandil on vascular endothelial function and the progression of arteriosclerosis. J. Cardiovasc. Pharmacol. 2005, 46, 63-67.

149. Yang, X.F. Chemiluminescence investigation of carbon dioxide-enhanced oxidation of dihydralazine sulfate by peroxynitrite and its application to pharmaceutical analysis. Anal. Chim. Acta 2008, 616, 190-195. 
150. Knowles, H.J.; Tian, Y.M.; Mole, D.R.; Harris, A.L. Novel mechanism of action for hydralazine: Induction of hypoxia-inducible factor- $1 \alpha$, vascular endothelial growth factor, and angiogenesis by inhibition of prolyl hydroxylases. Circ. Res. 2004, 95, 162-169.

151. Aslam, S. Cardiovascular disease in dialysis patients: Do some antihypertensive drugs have specific antioxidant effects or is it just blood pressure reduction? Does antioxidant treatment reduce the risk for cardiovascular disease? Curr. Opin. Nephrol. Hypertens. 2008, 17, 99-105.

152. Hoenig, M.R.; Bianchi, C.; Sellke, F.W. Hypoxia inducible factor-1 $\alpha$, endothelial progenitor cells, monocytes, cardiovascular risk, wound healing, cobalt and hydralazine: A unifying hypothesis. Curr. Drug Targets 2008, 9, 422-435.

153. Brehm, B.R.; Wolf, S.C.; Bertsch, D.; Klaussner, M.; Wesselborg, S.; Schuler, S.; Schulze-Osthoff, K. Effects of nebivolol on proliferation and apoptosis of human coronary artery smooth muscle and endothelial cells. Cardiovasc. Res. 2001, 49, 430-439.

154. Georgescu, A.; Pluteanu, F.; Flonta, M.L.; Badila, E.; Dorobantu, M.; Popov, D. The cellular mechanisms involved in the vasodilator effect of nebivolol on the renal artery. Eur. J. Pharmacol. 2005, 508, 159-166.

155. Broeders, M.A.; Doevendans, P.A.; Bekkers, B.C.; Bronsaer, R.; van Gorsel, E.; Heemskerk, J.W.; Egbrink, M.G.; van Breda, E.; Reneman, R.S.; van Der Zee, R. Nebivolol: A third-generation $\beta$-blocker that augments vascular nitric oxide release: Endothelial $\beta_{2}$-adrenergic receptor-Mediated nitric oxide production. Circulation 2000, 102, 677-684.

156. Tzemos, N.; Lim, P.O.; MacDonald, T.M. Nebivolol reverses endothelial dysfunction in essential hypertension: A randomized, double-blind, crossover study. Circulation 2001, 104, 511-514.

157. Mollnau, H.; Schulz, E.; Daiber, A.; Baldus, S.; Oelze, M.; August, M.; Wendt, M.; Walter, U.; Geiger, C.; Agrawal, R.; et al. Nebivolol prevents vascular nos III uncoupling in experimental hyperlipidemia and inhibits NADPH oxidase activity in inflammatory cells. Arterioscler. Thromb. Vasc. Biol. 2003, 23, 615-621.

158. Oelze, M.; Daiber, A.; Brandes, R.P.; Hortmann, M.; Wenzel, P.; Hink, U.; Schulz, E.; Mollnau, H.; von Sandersleben, A.; Kleschyov, A.L.; et al. Nebivolol inhibits superoxide formation by NADPH oxidase and endothelial dysfunction in angiotensin II-treated rats. Hypertension 2006, 48, 677-684.

159. Pasini, A.F.; Garbin, U.; Nava, M.C.; Stranieri, C.; Davoli, A.; Sawamura, T.; Cascio, V.L.; Cominacini, L. Nebivolol decreases oxidative stress in essential hypertensive patients and increases nitric oxide by reducing its oxidative inactivation. J. Hypertens. 2005, 23, 589-596.

160. Sorrentino, S.A.; Doerries, C.; Manes, C.; Speer, T.; Dessy, C.; Lobysheva, I.; Mohmand, W.; Akbar, R.; Bahlmann, F.; Besler, C.; et al. Nebivolol exerts beneficial effects on endothelial function, early endothelial progenitor cells, myocardial neovascularization, and left ventricular dysfunction early after myocardial infarction beyond conventional $\beta_{1}$-blockade. J. Am. Coll. Cardiol. 2011, 57, 601-611.

161. Munzel, T.; Daiber, A.; Mulsch, A. Explaining the phenomenon of nitrate tolerance. Circ. Res. 2005, 97, 618-628.

162. Gori, T.; Daiber, A. Non-hemodynamic effects of organic nitrates and the distinctive characteristics of pentaerithrityl tetranitrate. Am. J. Cardiovasc. Drugs. 2009, 9, 7-15. 
163. Munzel, T.; Meinertz, T.; Tebbe, U.; Schneider, H.T.; Stalleicken, D.; Wargenau, M.; Gori, T.; Klingmann, I.; Investigators, C.S. Efficacy of the long-acting nitro vasodilator pentaerithrityl tetranitrate in patients with chronic stable angina pectoris receiving anti-anginal background therapy with $\beta$-blockers: A 12-week, randomized, double-blind, placebo-controlled trial. Eur. Heart. J. 2014, 35, 895-903.

164. Schnorbus, B.; Schiewe, R.; Ostad, M.A.; Medler, C.; Wachtlin, D.; Wenzel, P.; Daiber, A.; Munzel, T.; Warnholtz, A. Effects of pentaerythritol tetranitrate on endothelial function in coronary artery disease: Results of the penta study. Clin. Res. Cardiol. 2010, 99, 115-124.

165. Schuhmacher, S.; Wenzel, P.; Schulz, E.; Oelze, M.; Mang, C.; Kamuf, J.; Gori, T.; Jansen, T.; Knorr, M.; Karbach, S.; et al. Pentaerythritol tetranitrate improves angiotensin II-induced vascular dysfunction via induction of heme oxygenase-1. Hypertension 2010, 55, 897-904.

166. Wenzel, P.; Oelze, M.; Coldewey, M.; Hortmann, M.; Seeling, A.; Hink, U.; Mollnau, H.; Stalleicken, D.; Weiner, H.; Lehmann, J.; et al. Heme oxygenase-1: A novel key player in the development of tolerance in response to organic nitrates. Arterioscler. Thromb. Vasc. Biol. 2007, 27, 1729-1735.

167. Oberle, S.; Abate, A.; Grosser, N.; Hemmerle, A.; Vreman, H.J.; Dennery, P.A.; Schneider, H.T.; Stalleicken, D.; Schroder, H. Endothelial protection by pentaerithrityl trinitrate: Bilirubin and carbon monoxide as possible mediators. Exp. Biol. Med. (Maywood) 2003, 228, 529-534.

168. Oberle, S.; Abate, A.; Grosser, N.; Vreman, H.J.; Dennery, P.A.; Schneider, H.T.; Stalleicken, D.; Schroder, H. Heme oxygenase-1 induction may explain the antioxidant profile of pentaerythrityl trinitrate. Biochem. Biophys. Res. Commun. 2002, 290, 1539-1544.

169. Schuhmacher, S.; Oelze, M.; Bollmann, F.; Kleinert, H.; Otto, C.; Heeren, T.; Steven, S.; Hausding, M.; Knorr, M.; Pautz, A.; et al. Vascular dysfunction in experimental diabetes is improved by pentaerithrityl tetranitrate but not isosorbide-5-mononitrate therapy. Diabetes 2011, 60, 2608-2616.

170. Oppermann, M.; Balz, V.; Adams, V.; Dao, V.T.; Bas, M.; Suvorava, T.; Kojda, G. Pharmacological induction of vascular extracellular superoxide dismutase expression in vivo. J. Cell. Mol. Med. 2009, 13, 1271-1278.

171. Hacker, A.; Muller, S.; Meyer, W.; Kojda, G. The nitric oxide donor pentaerythritol tetranitrate can preserve endothelial function in established atherosclerosis. Br. J. Pharmacol. 2001, 132, 1707-1714.

172. Flierl, U.; Fraccarollo, D.; Widder, J.D.; Micka, J.; Neuser, J.; Bauersachs, J.; Schafer, A. The nitric oxide donor pentaerythritol tetranitrate reduces platelet activation in congestive heart failure. PLoS ONE 2015, 10, e0123621.

173. Thum, T.; Fraccarollo, D.; Thum, S.; Schultheiss, M.; Daiber, A.; Wenzel, P.; Munzel, T.; Ertl, G.; Bauersachs, J. Differential effects of organic nitrates on endothelial progenitor cells are determined by oxidative stress. Arterioscler. Thromb. Vasc. Biol. 2007, 27, 748-754.

174. Thum, T.; Wiebking, V.; Ertl, G.; Bauersachs, J. Organic nitrates differentially modulate circulating endothelial progenitor cells and endothelial function in patients with symptomatic coronary artery disease. Antioxid. Redox Signal. 2011, 15, 925-931. 
175. DiFabio, J.M.; Thomas, G.R.; Zucco, L.; Kuliszewski, M.A.; Bennett, B.M.; Kutryk, M.J.; Parker, J.D. Nitroglycerin attenuates human endothelial progenitor cell differentiation, function, and survival. J. Pharmacol. Exp. Ther. 2006, 318, 117-123.

176. Pautz, A.; Rauschkolb, P.; Schmidt, N.; Art, J.; Oelze, M.; Wenzel, P.; Forstermann, U.; Daiber, A.; Kleinert, H. Effects of nitroglycerin or pentaerithrityl tetranitrate treatment on the gene expression in rat hearts: Evidence for cardiotoxic and cardioprotective effects. Physiol. Genom. 2009, 38, 176-185.

177. Wu, Z.; Siuda, D.; Xia, N.; Reifenberg, G.; Daiber, A.; Munzel, T.; Forstermann, U.; Li, H. Maternal treatment of spontaneously hypertensive rats with pentaerythritol tetranitrate reduces blood pressure in female offspring. Hypertension 2015, 65, 232-237.

178. Abbott, C.A.; Yu, D.M.; Woollatt, E.; Sutherland, G.R.; McCaughan, G.W.; Gorrell, M.D. Cloning, expression and chromosomal localization of a novel human dipeptidyl peptidase (DPP) IV homolog, DPP8. Eur. J. Biochem. 2000, 267, 6140-6150.

179. Zhong, J.; Rao, X.; Rajagopalan, S. An emerging role of dipeptidyl peptidase 4 (DPP4) beyond glucose control: Potential implications in cardiovascular disease. Atherosclerosis 2013, 226, 305-314.

180. Buhling, F.; Junker, U.; Reinhold, D.; Neubert, K.; Jager, L.; Ansorge, S. Functional role of CD26 on human B lymphocytes. Immunol. Lett. 1995, 45, 47-51.

181. Buhling, F.; Kunz, D.; Reinhold, D.; Ulmer, A.J.; Ernst, M.; Flad, H.D.; Ansorge, S. Expression and functional role of dipeptidyl peptidase IV (CD26) on human natural killer cells. Nat. Immun. 1994, 13, 270-279.

182. Gorrell, M.D. Dipeptidyl peptidase IV and related enzymes in cell biology and liver disorders. Clin. Sci. 2005, 108, 277-292.

183. Palmieri, F.E.; Ward, P.E. Dipeptidyl(amino)peptidase iv and post proline cleaving enzyme in cultured endothelial and smooth muscle cells. Adv. Exp. Med. Biol. 1989, 247A, 305-311.

184. Baggio, L.L.; Drucker, D.J. Biology of incretins: GLP-1 and GIP. Gastroenterology 2007, 132, 2131-2157.

185. Lund, P.K.; Goodman, R.H.; Dee, P.C.; Habener, J.F. Pancreatic preproglucagon cdna contains two glucagon-related coding sequences arranged in tandem. Proc. Natl. Acad. Sci. USA 1982, 79, 345-349.

186. Doyle, M.E.; Egan, J.M. Mechanisms of action of glucagon-like peptide 1 in the pancreas. Pharmacol. Ther. 2007, 113, 546-593.

187. Nauck, M.A. Incretin-based therapies for type 2 diabetes mellitus: Properties, functions, and clinical implications. Am. J. Med. 2011, 124, S3-18.

188. Brubaker, P.L.; Drucker, D.J. Structure-function of the glucagon receptor family of G protein-coupled receptors: The glucagon, GIP, GLP-1, and GLP-2 receptors. Recept. Channels 2002, 8, 179-188.

189. Mentlein, R.; Gallwitz, B.; Schmidt, W.E. Dipeptidyl-peptidase iv hydrolyses gastric inhibitory polypeptide, glucagon-like peptide-1(7-36)amide, peptide histidine methionine and is responsible for their degradation in human serum. Eur. J. Biochem. 1993, 214, 829-835. 
190. Kieffer, T.J.; McIntosh, C.H.; Pederson, R.A. Degradation of glucose-dependent insulinotropic polypeptide and truncated glucagon-like peptide 1 in vitro and in vivo by dipeptidyl peptidase IV. Endocrinology 1995, 136, 3585-3596.

191. International Diabetes Federation Guideline Development Group. Global guideline for type 2 diabetes. Diabetes Res. Clin. Pract. 2014, 104, 1-52.

192. Matsubara, J.; Sugiyama, S.; Sugamura, K.; Nakamura, T.; Fujiwara, Y.; Akiyama, E.; Kurokawa, H.; Nozaki, T.; Ohba, K.; Konishi, M.; et al. A dipeptidyl peptidase-4 inhibitor, des-fluoro-sitagliptin, improves endothelial function and reduces atherosclerotic lesion formation in apolipoprotein E-deficient mice. J. Am. Coll. Cardiol. 2012, 59, 265-276.

193. Shah, Z.; Kampfrath, T.; Deiuliis, J.A.; Zhong, J.; Pineda, C.; Ying, Z.; Xu, X.; Lu, B.; Moffatt-Bruce, S.; Durairaj, R.; et al. Long-term dipeptidyl-peptidase 4 inhibition reduces atherosclerosis and inflammation via effects on monocyte recruitment and chemotaxis. Circulation 2011, 124, 2338-2349.

194. Nishioka, T.; Shinohara, M.; Tanimoto, N.; Kumagai, C.; Hashimoto, K. Sitagliptin, a dipeptidyl peptidase-iv inhibitor, improves psoriasis. Dermatology 2012, 224, 20-21.

195. Kern, M.; Kloting, N.; Niessen, H.G.; Thomas, L.; Stiller, D.; Mark, M.; Klein, T.; Bluher, M. Linagliptin improves insulin sensitivity and hepatic steatosis in diet-induced obesity. PLoS ONE 2012, 7, e38744.

196. Darsalia, V.; Ortsater, H.; Olverling, A.; Darlof, E.; Wolbert, P.; Nystrom, T.; Klein, T.; Sjoholm, A.; Patrone, C. The DPP-4 inhibitor linagliptin counteracts stroke in the normal and diabetic mouse brain: A comparison with glimepiride. Diabetes 2013, 62, 1289-1296.

197. Huang, C.Y.; Shih, C.M.; Tsao, N.W.; Lin, Y.W.; Huang, P.H.; Wu, S.C.; Lee, A.W.; Kao, Y.T.; Chang, N.C.; Nakagami, H.; et al. Dipeptidyl peptidase-4 inhibitor improves neovascularization by increasing circulating endothelial progenitor cells. Br. J. Pharmacol. 2012, 167, 1506-1519.

198. Brenner, C.; Krankel, N.; Kuhlenthal, S.; Israel, L.; Remm, F.; Fischer, C.; Herbach, N.; Speer, T.; Grabmaier, U.; Laskowski, A.; et al. Short-term inhibition of DPP-4 enhances endothelial regeneration after acute arterial injury via enhanced recruitment of circulating progenitor cells. Int. J. Cardiol. 2014, 177, 266-275.

199. Fadini, G.P.; Boscaro, E.; Albiero, M.; Menegazzo, L.; Frison, V.; de Kreutzenberg, S.; Agostini, C.; Tiengo, A.; Avogaro, A. The oral dipeptidyl peptidase-4 inhibitor sitagliptin increases circulating endothelial progenitor cells in patients with type 2 diabetes: Possible role of stromal-derived factor-1 $\alpha$. Diabetes care 2010, 33, 1607-1609.

200. Xiao-Yun, X.; Zhao-Hui, M.; Ke, C.; Hong-Hui, H.; Yan-Hong, X. Glucagon-like peptide-1 improves proliferation and differentiation of endothelial progenitor cells via upregulating vegf generation. Med. Sci. Monit. 2011, 17, BR35-BR41.

201. Oeseburg, H.; de Boer, R.A.; Buikema, H.; van der Harst, P.; van Gilst, W.H.; Sillje, H.H. Glucagon-like peptide 1 prevents reactive oxygen species-induced endothelial cell senescence through the activation of protein kinase a. Arterioscler. Thromb. Vasc. biol. 2010, 30, 1407-1414.

202. Akarte, A.S.; Srinivasan, B.P.; Gandhi, S.; Sole, S. Chronic DPP-IV inhibition with PKF-275-055 attenuates inflammation and improves gene expressions responsible for insulin secretion in streptozotocin induced diabetic rats. Eur. J. Pharm. Sci. 2012, 47, 456-463. 
203. Chinda, K.; Palee, S.; Surinkaew, S.; Phornphutkul, M.; Chattipakorn, S.; Chattipakorn, N. Cardioprotective effect of dipeptidyl peptidase-4 inhibitor during ischemia-reperfusion injury. Int. J. Cardiol. 2013, 167, 451-457.

204. Inthachai, T.; Lekawanvijit, S.; Kumfu, S.; Apaijai, N.; Pongkan, W.; Chattipakorn, S.C.; Chattipakorn, N. Dipeptidyl peptidase-4 inhibitor improves cardiac function by attenuating adverse cardiac remodelling in rats with chronic myocardial infarction. Exp. Physiol. 2015, 100, 667-679.

205. Bao, W.; Morimoto, K.; Hasegawa, T.; Sasaki, N.; Yamashita, T.; Hirata, K.; Okita, Y.; Okada, K. Orally administered dipeptidyl peptidase-4 inhibitor (alogliptin) prevents abdominal aortic aneurysm formation through an antioxidant effect in rats. J. Vasc. Surg. 2014, 59, 1098-1108.

206. Abdelsalam, R.M.; Safar, M.M. Neuroprotective effects of vildagliptin in rat rotenone parkinson's disease model: Role of RAGE-NFkB and Nrf2-antioxidant signaling pathways. J. Neurochem. 2015, 133, 700-707.

207. Steven, S.; Hausding, M.; Kroller-Schon, S.; Mader, M.; Mikhed, Y.; Stamm, P.; Zinssius, E.; Pfeffer, A.; Welschof, P.; Agdauletova, S.; et al. Gliptin and GLP-1 analog treatment improves survival and vascular inflammation/dysfunction in animals with lipopolysaccharide-induced endotoxemia. Basic Res. Cardiol. 2015, 110, 6.

208. Kroller-Schon, S.; Knorr, M.; Hausding, M.; Oelze, M.; Schuff, A.; Schell, R.; Sudowe, S.; Scholz, A.; Daub, S.; Karbach, S.; et al. Glucose-independent improvement of vascular dysfunction in experimental sepsis by dipeptidyl-peptidase 4 inhibition. Cardiovasc. Res. 2012, 96, 140-149.

209. Shah, P.; Ardestani, A.; Dharmadhikari, G.; Laue, S.; Schumann, D.M.; Kerr-Conte, J.; Pattou, F.; Klein, T.; Maedler, K. The DPP-4 inhibitor linagliptin restores $\beta$-cell function and survival in human isolated islets through GLP-1 stabilization. J. Clin. Endocrinol. Metab. 2013, 98, E1163-E1172.

210. Rizzo, M.R.; Barbieri, M.; Marfella, R.; Paolisso, G. Reduction of oxidative stress and inflammation by blunting daily acute glucose fluctuations in patients with type 2 diabetes: Role of dipeptidyl peptidase-iv inhibition. Diabetes Care 2012, 35, 2076-2082.

211. Batchuluun, B.; Inoguchi, T.; Sonoda, N.; Sasaki, S.; Inoue, T.; Fujimura, Y.; Miura, D.; Takayanagi, R. Metformin and liraglutide ameliorate high glucose-induced oxidative stress via inhibition of PKC-NAD(P)H oxidase pathway in human aortic endothelial cells. Atherosclerosis 2014, 232, 156-164.

212. Shiraki, A.; Oyama, J.; Komoda, H.; Asaka, M.; Komatsu, A.; Sakuma, M.; Kodama, K.; Sakamoto, Y.; Kotooka, N.; Hirase, T.; et al. The glucagon-like peptide 1 analog liraglutide reduces TNF- $\alpha$-induced oxidative stress and inflammation in endothelial cells. Atherosclerosis 2012, 221, 375-382.

213. Salcedo, I.; Tweedie, D.; Li, Y.; Greig, N.H. Neuroprotective and neurotrophic actions of glucagon-like peptide-1: An emerging opportunity to treat neurodegenerative and cerebrovascular disorders. Br. J. Pharmacol. 2012, 166, 1586-1599.

214. Fisslthaler, B.; Fleming, I. Activation and signaling by the amp-activated protein kinase in endothelial cells. Circ. Res. 2009, 105, 114-127. 
215. Balteau, M.; van Steenbergen, A.; Timmermans, A.D.; Dessy, C.; Behets-Wydemans, G.; Tajeddine, N.; Castanares-Zapatero, D.; Gilon, P.; Vanoverschelde, J.L.; Horman, S.; et al. AMPK activation by glucagon-like peptide-1 prevents NADPH oxidase activation induced by hyperglycemia in adult cardiomyocytes. Am. J. Physiol. Heart Circ. Physiol. 2014, 307, H1120-H1133.

216. Martin, M.; Huguet, J.; Centelles, J.J.; Franco, R. Expression of ecto-adenosine deaminase and CD26 in human $\mathrm{T}$ cells triggered by the TCR-CD3 complex. Possible role of adenosine deaminase as costimulatory molecule. J. Immunol. 1995, 155, 4630-4643.

217. Kameoka, J.; Tanaka, T.; Nojima, Y.; Schlossman, S.F.; Morimoto, C. Direct association of adenosine deaminase with a $T$ cell activation antigen, CD26. Science 1993, 261, 466-469.

218. Dopheide, J.F.; Scheer, M.; Doppler, C.; Obst, V.; Stein, P.; Vosseler, M.; Abegunewardene, N.; Gori, T.; Munzel, T.; Daiber, A.; et al. Change of walking distance in intermittent claudication: Impact on inflammation, oxidative stress and mononuclear cells: A pilot study. Clin. Res. Cardiol. 2015, doi:10.1007/s00392-015-0840-5.

219. Dopheide, J.F.; Obst, V.; Doppler, C.; Radmacher, M.C.; Scheer, M.; Radsak, M.P.; Gori, T.; Warnholtz, A.; Fottner, C.; Daiber, A.; et al. Phenotypic characterisation of pro-inflammatory monocytes and dendritic cells in peripheral arterial disease. Thromb. Haemost. 2012, 108, 1198-1207.

220. Dopheide, J.F.; Doppler, C.; Scheer, M.; Obst, V.; Radmacher, M.C.; Radsak, M.P.; Gori, T.; Warnholtz, A.; Fottner, C.; Munzel, T.; et al. Critical limb ischaemia is characterised by an increased production of whole blood reactive oxygen species and expression of TREM-1 on neutrophils. Atherosclerosis 2013, 229, 396-403.

221. Libby, P. Inflammation in atherosclerosis. Arterioscler. Thromb. Vasc. Biol. 2012, 32, 2045-2051.

222. Burgmaier, M.; Liberman, A.; Mollmann, J.; Kahles, F.; Reith, S.; Lebherz, C.; Marx, N.; Lehrke, M. Glucagon-like peptide-1 (GLP-1) and its split products GLP-1(9-37) and GLP-1(28-37) stabilize atherosclerotic lesions in apoe ${ }^{-/-}$mice. Atherosclerosis 2013, 231, 427-435.

223. Gaspari, T.; Liu, H.; Welungoda, I.; Hu, Y.; Widdop, R.E.; Knudsen, L.B.; Simpson, R.W.; Dear, A.E. A GLP-1 receptor agonist liraglutide inhibits endothelial cell dysfunction and vascular adhesion molecule expression in an apoe ${ }^{-1-}$ mouse model. Diabetes Vasc. Dis. Res. 2011, 8, 117-124.

224. Buldak, L.; Labuzek, K.; Buldak, R.J.; Machnik, G.; Boldys, A.; Okopien, B. Exenatide (a GLP-1 agonist) improves the antioxidative potential of in vitro cultured human monocytes/macrophages. Naunyn Schmiedebergs Arch. Pharmacol. 2015, in press.

225. Arakawa, M.; Mita, T.; Azuma, K.; Ebato, C.; Goto, H.; Nomiyama, T.; Fujitani, Y.; Hirose, T.; Kawamori, R.; Watada, H. Inhibition of monocyte adhesion to endothelial cells and attenuation of atherosclerotic lesion by a glucagon-like peptide-1 receptor agonist, exendin-4. Diabetes $\mathbf{2 0 1 0}$, 59, 1030-1037.

226. Erdogdu, O.; Nathanson, D.; Sjoholm, A.; Nystrom, T.; Zhang, Q. Exendin-4 stimulates proliferation of human coronary artery endothelial cells through eNOS-, PKA- and PI3K/Akt-dependent pathways and requires GLP-1 receptor. Mol. Cell. Endocrinol. 2010, 325, 26-35. 
227. Ban, K.; Noyan-Ashraf, M.H.; Hoefer, J.; Bolz, S.S.; Drucker, D.J.; Husain, M. Cardioprotective and vasodilatory actions of glucagon-like peptide 1 receptor are mediated through both glucagon-like peptide 1 receptor-dependent and -independent pathways. Circulation 2008, 117, 2340-2350.

228. Green, B.D.; Hand, K.V.; Dougan, J.E.; McDonnell, B.M.; Cassidy, R.S.; Grieve, D.J. GLP-1 and related peptides cause concentration-dependent relaxation of rat aorta through a pathway involving katp and camp. Arch. Biochem. Biophys. 2008, 478, 136-142.

229. Shah, Z.; Pineda, C.; Kampfrath, T.; Maiseyeu, A.; Ying, Z.; Racoma, I.; Deiuliis, J.; Xu, X.; Sun, Q.; Moffatt-Bruce, S.; et al. Acute DPP-4 inhibition modulates vascular tone through GLP-1 independent pathways. Vascul. Pharmacol. 2011, 55, 2-9.

230. Wang, R.; Lu, L.; Guo, Y.; Lin, F.; Chen, H.; Chen, W.; Chen, M. Effect of glucagon-like peptide-1 on high-glucose-induced oxidative stress and cell apoptosis in human endothelial cells and its underlying mechanism. J. Cardiovasc. Pharmacol. 2015, doi:10.1097/ FJC.0000000000000255.

231. Levy, M.M.; Artigas, A.; Phillips, G.S.; Rhodes, A.; Beale, R.; Osborn, T.; Vincent, J.L.; Townsend, S.; Lemeshow, S.; Dellinger, R.P. Outcomes of the surviving sepsis campaign in intensive care units in the USA and europe: A prospective cohort study. Lancet Infect. Dis. 2012, 12, 919-924.

232. Levi, M.; van der Poll, T. Disseminated intravascular coagulation: A review for the internist. Intern. Emerg. Med. 2013, 8, 23-32.

233. Boerma, E.C.; van der Voort, P.H.; Spronk, P.E.; Ince, C. Relationship between sublingual and intestinal microcirculatory perfusion in patients with abdominal sepsis. Crit. Care Med. 2007, 35, 1055-1060.

234. Bone, R.C. Sepsis syndrome. New insights into its pathogenesis and treatment. Infect. Dis. Clin. N. Am. 1991, 5, 793-805.

235. Nguyen, H.B.; Rivers, E.P.; Knoblich, B.P.; Jacobsen, G.; Muzzin, A.; Ressler, J.A.; Tomlanovich, M.C. Early lactate clearance is associated with improved outcome in severe sepsis and septic shock. Crit. Care Med. 2004, 32, 1637-1642.

236. Gkaliagkousi, E.; Ferro, A. Nitric oxide signalling in the regulation of cardiovascular and platelet function. Front. Biosci. 2011, 16, 1873-1897.

237. Huet, O.; Dupic, L.; Harrois, A.; Duranteau, J. Oxidative stress and endothelial dysfunction during sepsis. Front. Biosci. 2011, 16, 1986-1995.

238. Krotz, F.; Sohn, H.Y.; Pohl, U. Reactive oxygen species: Players in the platelet game. Arterioscler. Thromb. Vasc. Biol. 2004, 24, 1988-1996.

239. Heyworth, P.G.; Cross, A.R.; Curnutte, J.T. Chronic granulomatous disease. Curr. Opin. Immunol. 2003, 15, 578-584.

240. Nathens, A.B.; Neff, M.J.; Jurkovich, G.J.; Klotz, P.; Farver, K.; Ruzinski, J.T.; Radella, F.; Garcia, I.; Maier, R.V. Randomized, prospective trial of antioxidant supplementation in critically ill surgical patients. Ann. Surg. 2002, 236, 814-822.

241. Domenighetti, G.; Suter, P.M.; Schaller, M.D.; Ritz, R.; Perret, C. Treatment with $N$-acetylcysteine during acute respiratory distress syndrome: A randomized, double-blind, placebo-controlled clinical study. J. Crit. Care 1997, 12, 177-182. 
242. Sprung, C.L.; Annane, D.; Keh, D.; Moreno, R.; Singer, M.; Freivogel, K.; Weiss, Y.G.; Benbenishty, J.; Kalenka, A.; Forst, H.; et al. Hydrocortisone therapy for patients with septic shock. N. Engl. J. Med. 2008, 358, 111-124.

243. National Heart, L.; Blood Institute, A.C.T.N.; Truwit, J.D.; Bernard, G.R.; Steingrub, J.; Matthay, M.A.; Liu, K.D.; Albertson, T.E.; Brower, R.G.; Shanholtz, C.; et al. Rosuvastatin for sepsis-associated acute respiratory distress syndrome. N. Engl. J. Med. 2014, 370, 2191-2200.

244. Ku, H.C.; Chen, W.P.; Su, M.J. GLP-1 signaling preserves cardiac function in endotoxemic fischer 344 and DPP4-deficient rats. Naunyn Schmiedebergs Arch. Pharmacol. 2010, 382, 463-474.

245. Amori, R.E.; Lau, J.; Pittas, A.G. Efficacy and safety of incretin therapy in type 2 diabetes: Systematic review and meta-analysis. JAMA 2007, 298, 194-206.

246. Wang, Y.; Parlevliet, E.T.; Geerling, J.J.; van der Tuin, S.J.; Zhang, H.; Bieghs, V.; Jawad, A.H.; Shiri-Sverdlov, R.; Bot, I.; de Jager, S.C.; et al. Exendin-4 decreases liver inflammation and atherosclerosis development simultaneously by reducing macrophage infiltration. Br. J. Pharmacol. 2014, 171, 723-734.

247. Jung, Y.A.; Choi, Y.K.; Jung, G.S.; Seo, H.Y.; Kim, H.S.; Jang, B.K.; Kim, J.G.; Lee, I.K.; Kim, M.K.; Park, K.G. Sitagliptin attenuates methionine/choline-deficient diet-induced steatohepatitis. Diabetes Res. Clin. Pract. 2014, 105, 47-57.

248. Weng, S.Y.; Schuppan, D. AMPK regulates macrophage polarization in adipose tissue inflammation and NASH. J. Hepatol. 2013, 58, 619-621.

249. Iwaya, H.; Fujii, N.; Hagio, M.; Hara, H.; Ishizuka, S. Contribution of dipeptidyl peptidase IV to the severity of dextran sulfate sodium-induced colitis in the early phase. Biosci. Biotechnol. Biochem. 2013, 77, 1461-1466.

250. Schade, J.; Schmiedl, A.; Kehlen, A.; Veres, T.Z.; Stephan, M.; Pabst, R.; von Horsten, S. Airway-specific recruitment of $\mathrm{T}$ cells is reduced in a CD26-deficient F344 rat substrain. Clin. Exp. Immunol. 2009, 158, 133-142.

251. Viby, N.E.; Isidor, M.S.; Buggeskov, K.B.; Poulsen, S.S.; Hansen, J.B.; Kissow, H. Glucagon-like peptide-1 (GLP-1) reduces mortality and improves lung function in a model of experimental obstructive lung disease in female mice. Endocrinology 2013, 154, 4503-4511.

252. Busso, N.; Wagtmann, N.; Herling, C.; Chobaz-Peclat, V.; Bischof-Delaloye, A.; So, A.; Grouzmann, E. Circulating CD26 is negatively associated with inflammation in human and experimental arthritis. Am. J. Pathol. 2005, 166, 433-442.

253. Ridker, P.M.; Cannon, C.P.; Morrow, D.; Rifai, N.; Rose, L.M.; McCabe, C.H.; Pfeffer, M.A.; Braunwald, E.; Pravastatin or Atorvastatin, E.; Infection Therapy-Thrombolysis in Myocardial Infarction, I. C-reactive protein levels and outcomes after statin therapy. N. Engl. J. Med. 2005, $352,20-28$.

254. Zhu, F.; Wang, Q.; Guo, C.; Wang, X.; Cao, X.; Shi, Y.; Gao, F.; Ma, C.; Zhang, L. IL-17 induces apoptosis of vascular endothelial cells: A potential mechanism for human acute coronary syndrome. Clin. Immunol. 2011, 141, 152-160.

255. Huppert, J.; Closhen, D.; Croxford, A.; White, R.; Kulig, P.; Pietrowski, E.; Bechmann, I.; Becher, B.; Luhmann, H.J.; Waisman, A.; et al. Cellular mechanisms of IL-17-induced blood-brain barrier disruption. FASEB J. 2010, 24, 1023-1034. 
256. Roussel, L.; Houle, F.; Chan, C.; Yao, Y.; Berube, J.; Olivenstein, R.; Martin, J.G.; Huot, J.; Hamid, Q.; Ferri, L.; et al. IL-17 promotes p38 MAPK-dependent endothelial activation enhancing neutrophil recruitment to sites of inflammation. J. Immunol. 2010, 184, 4531-4537.

257. Hoch, N.E.; Guzik, T.J.; Chen, W.; Deans, T.; Maalouf, S.A.; Gratze, P.; Weyand, C.; Harrison, D.G. Regulation of t-cell function by endogenously produced angiotensin II. Am. J. Physiol. Regul. Integr. Comp. Physiol. 2009, 296, R208-R216.

258. Geiger, H. T-cells in angiotensin-II-induced vascular damage. Nephrol. Dial. Transplant. 2008, 23, 1107-1108.

259. Micha, R.; Imamura, F.; Wyler von Ballmoos, M.; Solomon, D.H.; Hernan, M.A.; Ridker, P.M.; Mozaffarian, D. Systematic review and meta-analysis of methotrexate use and risk of cardiovascular disease. Am. J. Cardiol. 2011, 108, 1362-1370.

260. Asanuma, H.; Sanada, S.; Ogai, A.; Minamino, T.; Takashima, S.; Asakura, M.; Ogita, H.; Shinozaki, Y.; Mori, H.; Node, K.; et al. Methotrexate and MX-68, a new derivative of methotrexate, limit infarct size via adenosine-dependent mechanisms in canine hearts. J. Cardiovasc. Pharmacol. 2004, 43, 574-579.

261. Moreira, D.M.; Lueneberg, M.E.; da Silva, R.L.; Fattah, T.; Mascia Gottschall, C.A. Rationale and design of the tethys trial: The effects of methotrexate therapy on myocardial infarction with ST-segment elevation. Cardiology 2013, 126, 167-170.

262. Everett, B.M.; Pradhan, A.D.; Solomon, D.H.; Paynter, N.; Macfadyen, J.; Zaharris, E.; Gupta, M.; Clearfield, M.; Libby, P.; Hasan, A.A.; et al. Rationale and design of the cardiovascular inflammation reduction trial: A test of the inflammatory hypothesis of atherothrombosis. Am. Heart J. 2013, 166, 199-207 e115.

263. Elhage, R.; Maret, A.; Pieraggi, M.T.; Thiers, J.C.; Arnal, J.F.; Bayard, F. Differential effects of interleukin-1 receptor antagonist and tumor necrosis factor binding protein on fatty-streak formation in apolipoprotein E-deficient mice. Circulation 1998, 97, 242-244.

264. Chi, H.; Messas, E.; Levine, R.A.; Graves, D.T.; Amar, S. Interleukin-1 receptor signaling mediates atherosclerosis associated with bacterial exposure and/or a high-fat diet in a murine apolipoprotein e heterozygote model: Pharmacotherapeutic implications. Circulation 2004, 110, 1678-1685.

265. Ridker, P.M.; Howard, C.P.; Walter, V.; Everett, B.; Libby, P.; Hensen, J.; Thuren, T.; Group, C.P.I. Effects of interleukin-1 $\beta$ inhibition with canakinumab on hemoglobin A1c, lipids, C-reactive protein, interleukin-6, and fibrinogen: A phase IIB randomized, placebo-controlled trial. Circulation 2012, 126, 2739-2748.

266. Munzel, T.; Sinning, C.; Post, F.; Warnholtz, A.; Schulz, E. Pathophysiology, diagnosis and prognostic implications of endothelial dysfunction. Ann. Med. 2008, 40, 180-196.

267. Munzel, T.; Gori, T.; Bruno, R.M.; Taddei, S. Is oxidative stress a therapeutic target in cardiovascular disease? Eur. Heart. J. 2010, 31, 2741-2748.

268. Zhang, L.; Zalewski, A.; Liu, Y.; Mazurek, T.; Cowan, S.; Martin, J.L.; Hofmann, S.M.; Vlassara, H.; Shi, Y. Diabetes-induced oxidative stress and low-grade inflammation in porcine coronary arteries. Circulation 2003, 108, 472-478.

269. Steinhubl, S.R. Why have antioxidants failed in clinical trials? Am. J. Cardiol. 2008, 101, 14D-19D. 
270. Warnholtz, A.; Genth-Zotz, S.; Munzel, T. Should treatment of sepsis include statins? Circulation 2005, 111, 1735-1737.

271. Merx, M.W.; Liehn, E.A.; Janssens, U.; Lutticken, R.; Schrader, J.; Hanrath, P.; Weber, C. HMG-CoA reductase inhibitor simvastatin profoundly improves survival in a murine model of sepsis. Circulation 2004, 109, 2560-2565.

272. Deshpande, A.; Pasupuleti, V.; Rothberg, M.B. Statin therapy and mortality from sepsis: A meta-analysis of randomized trials. Am. J. Med. 2015, 128, 410-417 e411.

(C) 2015 by the authors; licensee MDPI, Basel, Switzerland. This article is an open access article distributed under the terms and conditions of the Creative Commons Attribution license (http://creativecommons.org/licenses/by/4.0/). 